\title{
Preparation of transition metal-containing layered double hydroxides and application to the photocatalytic conversion of $\mathrm{CO}_{2}$ in water
}

\section{Corresponding authors}

Prof. Kentaro Teramura and Prof. Tsunehiro Tanaka

Department of Molecular Engineering, Graduate School of Engineering, Kyoto University, KyotodaigakuKatsura, Nishikyo-ku, Kyoto 615-8510, Japan

Tel: +81-75-383-2559 Fax: +81-75-383-2561

E-mail address: teramura@moleng.kyoto-u.ac.jp

\section{List of the authors}

Shoji Iguchi ${ }^{\mathrm{a}}$,YudaiHasegawa ${ }^{\mathrm{a}}$, Kentaro Teramura, ${ }^{\mathrm{a}, \mathrm{b}, \mathrm{c}^{*}}$, SaburoHosokawa ${ }^{\mathrm{a}, \mathrm{b}}$, and Tsunehiro Tanaka, ${ }^{\mathrm{a}, \mathrm{b}^{*}}$

\section{Affiliation and full postal address}

a. Department of Molecular Engineering, Graduate School of Engineering, Kyoto University, KyotodaigakuKatsura, Nishikyo-ku, Kyoto 615-8510, Japan

b. Elements Strategy Initiative for Catalysts \& Batteries (ESICB), Kyoto University, 1-30 Goryo-Ohara, Nishikyo-ku, Kyoto 615-8245, Japan

c. Precursory Research for Embryonic Science and Technology (PRESTO), Japan Science and Technology Agency (JST), 4-1-8 Honcho, Kawaguchi, Saitama 332-0012, Japan 


\section{Abstract}

2 Layered double hydroxides (LDHs) have been paid great attention in the field of

3 the photocatalysis due to their interesting physicochemical properties such as positively

4 charged hydroxide sheet, compositional flexibilities, and large surface area. We

5 previously reported that the use of $\mathrm{Ni}-\mathrm{Al} \mathrm{LDH}$ as a photocatalyst enabled us to achieve

6 the maximum conversion of $\mathrm{CO}_{2}$ to $\mathrm{CO}$ with high selectivity among a series of

7 synthesized LDHs, and chloride ions $\left(\mathrm{Cl}^{-}\right)$in the reaction solution enhanced the amount

8 of $\mathrm{CO}$ evolved. In this study, we attempted to prepare 16 different kinds of transition

9 metal containing $\mathrm{M}^{2+}-\mathrm{M}^{3+} \mathrm{LDHs}\left(\mathrm{M}^{2+}=\mathrm{Co}^{2+}, \mathrm{Ni}^{2+}, \mathrm{Cu}^{2+}\right.$, and $\mathrm{Zn}^{2+} ; \mathrm{M}^{3+}=\mathrm{V}^{3+}, \mathrm{Cr}^{3+}$,

$10 \mathrm{Mn}^{3+}$, and $\mathrm{Fe}^{3+}$ ) and applied them to the photocatalytic conversion of $\mathrm{CO}_{2}$ in an aqueous

11 solution of $\mathrm{NaCl}$. $\mathrm{Ni}-\mathrm{V} \mathrm{LDH}$, which has large specific surface area, exhibited the

12 highest activity for the $\mathrm{CO}$ evolution among these LDHs; however the formation of

$13 \mathrm{H}_{2}$ as a reduction product of protons $\left(\mathrm{H}^{+}\right)$was totally suppressed. It is estimated that a

14 combination of $\mathrm{V}^{3+}$ and $\mathrm{Cl}^{-}$plays a significant role for the high photocatalytic activity and the high selectivity toward $\mathrm{CO}$ formation. 
S. Iguchi et al.

\section{Keywords}

2 Photocatalysis

$3 \quad \mathrm{CO}_{2}$ conversion

$4 \quad$ Layered double hydroxide (LDH)

$5 \quad \mathrm{Ni}-\mathrm{V}$ LDH 
1

2

$3\left[\mathrm{M}^{2+}{ }_{1-x}-\mathrm{M}^{3+}{ }_{x}(\mathrm{OH})_{2}\right]\left(\mathrm{A}^{n-}\right)_{x / n} \cdot m \mathrm{H}_{2} \mathrm{O}$ are known as anionic clays that have highly

\section{Introduction}

Layered double hydroxides (LDHs) with a general formula of ordered layer structures in the $c$-axis direction, where $\mathrm{M}^{2+}$ and $\mathrm{M}^{3+}$ are divalent and trivalent cations, respectively[1,2]. The value of $x$ represents the molar ratio of $\mathrm{M}^{3+} /\left(\mathrm{M}^{2+}+\mathrm{M}^{3+}\right)$, whereas $\mathrm{A}^{n-}$ is the interlayer anion of valence $n$. Generally, the value of mindicates the extent of hydration, which is highly influenced by the surrounding environment such as atmosphere, temperature, and humidity. The natures of $\mathrm{M}^{2+}, \mathrm{M}^{3+}, x$, and $\mathrm{A}^{n-}$ can vary over a wide range; hence, a series of isostructural materials with various chemical properties can be synthesized[3]. When the $x$ value is outside of the 0.2-0.4 range, hydroxides or other compounds can form as impurity phases. The best-known LDH material is hydrotalcite, which has a structural formula of $\mathrm{Mg}_{6} \mathrm{Al}_{2}(\mathrm{OH})_{16} \mathrm{CO}_{3} \cdot 4 \mathrm{H}_{2} \mathrm{O}$. Various LDHs can be formed by fully or partially replacing $\mathrm{Mg}^{2+}$ or $\mathrm{Al}^{3+}$ with divalent $\left(\mathrm{M}^{2+}=\mathrm{Fe}^{2+}, \mathrm{Co}^{2+}, \mathrm{Ni}^{2+}, \mathrm{Cu}^{2+}, \mathrm{Zn}^{2+}, \mathrm{Mn}^{2+}, \mathrm{Cd}^{2+}\right.$, and $\left.\mathrm{Ca}^{2+}\right)$ or trivalent cations $\left(\mathrm{M}^{3+}=\mathrm{Co}^{3+}, \mathrm{Fe}^{3+}, \mathrm{Mn}^{3+}, \mathrm{Ga}^{3+}, \mathrm{Cr}^{3+}, \mathrm{In}^{3+}, \mathrm{V}^{3+}, \mathrm{Y}^{3+}\right.$, and $\left.\mathrm{La}^{3+}\right)$, respectively [4-20]. Moreover, tetravalent cations $\left(\mathrm{M}^{4+}=\mathrm{Ti}^{4+}, \mathrm{Zr}^{4+}\right.$, and $\left.\mathrm{Sn}^{4+}\right)$ are also reported to form LDH structures[21-28]; however, $\mathrm{M}^{4+}$ cations sometimes form amorphous oxides instead of incorporating within the hydroxide sheets. Recently, various LDHs have been applied to photocatalytic reactions such as degradation of organic compounds, water splitting, and conversion of $\mathrm{CO}_{2}$. For example, García et al. reported that various $\mathrm{Zn}^{2+}$-containing $\mathrm{LDHs}(\mathrm{Zn}-\mathrm{Cr}, \mathrm{Zn}-\mathrm{Ti}$, and $\mathrm{Zn}-\mathrm{Ce} \mathrm{LDHs}$ ) exhibited photocatalytic activity for $\mathrm{O}_{2}$ evolution from an aqueous solution of $\mathrm{AgNO}_{3}$ under visible light irradiation[18]. On the other hand, photocatalytic $\mathrm{H}_{2}$ production from water,with lactic acid as a sacrificial electron donor,was demonstrated using $\mathrm{Ni}-\mathrm{Ti}$, 
$1 \mathrm{Zn}-\mathrm{Ti}$, and $\mathrm{Mg}-\mathrm{Al}-\mathrm{Ti}$ LDHs under visible light irradiation[26]. In addition,

2 photocatalytic degradations of dyes and organic compounds using a series of LDHs as

3 photocatalystshavealso been recently introduced [9,24,25,29-37].

4 Photocatalytic conversion of $\mathrm{CO}_{2}$ into valued chemicals such as $\mathrm{CO}, \mathrm{HCHO}$,

$5 \mathrm{HCOOH}, \mathrm{CH}_{3} \mathrm{OH}$, and $\mathrm{CH}_{4}$ is one of the most promising methods to construct a

6 sustainable carbon cycling system. We have previously reported that $\mathrm{ZrO}_{2}[38-41]$,

$7 \mathrm{MgO}[42,43]$, and $\mathrm{Ga}_{2} \mathrm{O}_{3}[44]$, on which basic surface sites were suitable for the

8 adsorption of $\mathrm{CO}_{2}$ molecules, showed photocatalytic activity for the conversion of $\mathrm{CO}_{2}$

9 to $\mathrm{CO}$ in gas phase using $\mathrm{H}_{2}$ as a reductant. $\mathrm{CO}_{2}$ molecules that are adsorbed on the

10 basic sites of these materials can be altered into active species, which is necessary for

11 the photocatalytic conversion of $\mathrm{CO}_{2}$, as shown in previous literature $[43,44]$.

12 Accordingly, solid base materials are promising candidates to developa photocatalytic

13 system for the conversion of $\mathrm{CO}_{2}$. From this viewpoint, we attempted to apply

14 synthesized LDHs to the photocatalytic conversion of $\mathrm{CO}_{2}$ into $\mathrm{CO}$ in water, and found

15 that various $\mathrm{M}^{2+}-\mathrm{M}^{3+}$ LDHs $\left(\mathrm{M}^{2+}=\mathrm{Mg}^{2+}, \mathrm{Ni}^{2+}\right.$, and $\mathrm{Zn}^{2+} ; \mathrm{M}^{3+}=\mathrm{Al}^{3+}, \mathrm{Ga}^{3+}$, and $\left.\mathrm{In}^{3+}\right)$

16 exhibited photocatalytic activity[45]. For the case of LDH photocatalyst, large specific

17 area and high affinity for $\mathrm{CO}_{2}$ molecules might facilitate the selective conversion of

$18 \mathrm{CO}_{2}$ under illumination.Similarly, Izumi et al. and Katsumata et al. also reported the

19 photocatalytic conversion of $\mathrm{CO}_{2}$ using $\mathrm{Cu}$-containing $\mathrm{LDHs}[46-48]$ and noble

20 metal-loaded LDHs[49], respectively. In our previous study, $\mathrm{Ni}-\mathrm{Al} \mathrm{LDH}$, in particular,

21 showed high activity and selectivity for CO formation among a series of LDHs; the

22 amount of $\mathrm{H}_{2}$ evolved as a reduction product of protons $\left(\mathrm{H}^{+}\right)$derived from water was

23 much smaller than those of the other LDHs[50]. Isotopic experiments using ${ }^{13} \mathrm{CO}_{2}$ as a

24 substrate revealed that the $\mathrm{CO}$ evolved in the photocatalytic reaction over these LDHs 
1 originated from the introduced $\mathrm{CO}_{2}$ substrate. The addition of chloride ions $\left(\mathrm{Cl}^{-}\right)$to the

2 reaction solution promoted the conversion of $\mathrm{CO}_{2}$ to $\mathrm{CO}$, and we confirmed that during

3 the photocatalytic reaction, a stoichiometric amount of hypochlorous acid ( $\mathrm{HClO})$ was

4 produced as an oxidation product of $\mathrm{Cl}^{-}$in the reaction solution, which was quantified

5 by $N, N$ '-diethyl- $p$-phenylenediamine (DPD) tests[51,52]. This indicated that $\mathrm{Cl}^{-}$can act

6 as a hole scavenger and is oxidized into chlorine $\left(\mathrm{Cl}_{2}\right)$, which is immediately

7 transformed into $\mathrm{HClO}$ in water[53]. In this study, wesynthesized various transition

8 metal-containing $\mathrm{M}^{2+}-\mathrm{M}^{3+} \mathrm{LDHs}\left(\mathrm{M}^{2+}=\mathrm{Co}^{2+}, \mathrm{Ni}^{2+}, \mathrm{Cu}^{2+}\right.$, and $\mathrm{Zn}^{2+} ; \mathrm{M}^{3+}=\mathrm{V}^{3+}, \mathrm{Cr}^{3+}$,

$9 \mathrm{Mn}^{3+}$, and $\mathrm{Fe}^{3+}$ ) and investigated their photocatalytic activities for the conversion of

$10 \mathrm{CO}_{2}$ in an aqueous NaClsolution under UV light irradiation. 


\section{Experimental Section}

\section{Catalyst preparation}

3 Various $\mathrm{M}^{2+}-\mathrm{M}^{3+}$ layered double hydroxides $\left(\mathrm{M}^{2+}-\mathrm{M}^{3+} \mathrm{LDHs}, \mathrm{M}^{2+}=\mathrm{Co}^{2+}, \mathrm{Ni}^{2+}\right.$,

$4 \mathrm{Cu}^{2+}$, and $\mathrm{Zn}^{2+} ; \mathrm{M}^{3+}=\mathrm{V}^{3+}, \mathrm{Cr}^{3+}, \mathrm{Mn}^{3+}$, and $\mathrm{Fe}^{3+}$ ) were synthesized by a typical

5 co-precipitation method, unless otherwise noted, with that the ratio of $\mathrm{M}^{2+}$ to $\mathrm{M}^{3+}$

$6\left(\mathrm{M}^{2+} / \mathrm{M}^{3+}\right)$ was fixed at 2. A mixed aqueous solution of precursors $\left(\mathrm{M}^{2+} \mathrm{Cl}_{2}\right.$ and $\left.\mathrm{M}^{3+} \mathrm{Cl}_{3}\right)$

7 was slowly dropped to an aqueous solution of $\mathrm{Na}_{2} \mathrm{CO}_{3}$ at room temperature with a

8 vigorous stirring. The $\mathrm{pH}$ was kept stable by adding an aqueous solution of $\mathrm{NaOH}$

9 during the precipitation using a liquid feeding pump (NRP-76, Nissin Rika) connected

10 to a $\mathrm{pH}$ controller (NPH-660NDE, Nissin Rika). The resulting suspension was aged at

$11333 \mathrm{~K}$ for $24 \mathrm{~h}$ with the stirring. The solid was collected by the suction filtration and

12 rinsed with $1.0 \mathrm{~L}$ of ultra-pure water, and then dried at $333 \mathrm{~K}$ in a vacuum oven.

13 Organic chemicals and solvents were not used throughout each step of the LDH

14 preparation procedure to prevent a contamination of carbon residue in the photocatalytic

15 reaction.

17 Catalyst characterization

18 The powder X-ray diffraction (XRD) patterns of prepared $\mathrm{M}^{2+}-\mathrm{M}^{3+} \mathrm{LDHs}$ were measured by an X-ray diffractometer (Ultime IV, Rigaku), using $\mathrm{Cu} \mathrm{K}_{\alpha}$ radiation $(\lambda=$ $0.154 \mathrm{~nm}$ ) at a scan rate of $4.0^{\circ} \mathrm{min}^{-1}$. The morphology of these as-synthesized samples

21 were investigated from SEM images, which were captured by using a field emission 22 scanning electron microscope (SU-8220, Hitachi High-Technologies) at an acceleration 23 voltage of $3.0 \mathrm{kV}$. The specific surface areas of LDHs were estimated from their $\mathrm{N}_{2}$ 24 adsorption isotherms at $77 \mathrm{~K}$ via $\mathrm{BET}$ method using an adsorption analyzer 
1 (BELSORP-miniII, BEL Japan). Prior to the measurements, each sample was evacuated

2 at $383 \mathrm{~K}$ for $1 \mathrm{~h}$ using a pretreatment system (BELPREP-vacII, BEL Japan). The

3 thermal analysis for the prepared LDHs were performed using athermobalance (Thermo

4 Plus 2, Rigaku). A certain amount of sample powder was set in the furnace, and the

5 change of sample weight was recorded with the increasing temperatureunder a dried air

6 flowing at a flow rate of $80 \mathrm{~mL} \mathrm{~min}^{-1}$. UV/Vis diffuse reflectance spectra of LDHs were

7 obtained using a UV-Vis Spectrometer (V-670, JASCO) equipped with an integrated

8 sphere accessory.

9

10 Photocatalytic conversion of $\mathrm{CO}_{2}$ in an aqueous solution

11 The photocatalytic conversion of $\mathrm{CO}_{2}$ in an aqueous solution of $\mathrm{NaCl}$ was carried out 12 using an inner-irradiation type reaction vessel under $\mathrm{CO}_{2}$ gas flow. $0.5 \mathrm{~g}$ of 13 as-synthesized photocatalyst powder was dispersed in $1.0 \mathrm{~L}$ of an aqueous solution of $14 \mathrm{NaCl}(0.1 \mathrm{M})$, and $\mathrm{He}$ or $\mathrm{CO}_{2}$ gas was bubbled into the suspension to degas the 15 dissolved air. The suspension was illuminated with a $400 \mathrm{~W}$ high-pressure mercury 16 lamp through a quartz filter equipped with a cooling water system under a flow of $\mathrm{CO}_{2}$ 17 gas at a flow rate of $15 \mathrm{~mL} \min ^{-1}$. The products such as $\mathrm{CO}, \mathrm{H}_{2}$, and $\mathrm{O}_{2}$ were analyzed 18 by a barrier discharge ionization detector (BID) gas chromatograph (GC-2010 Tracera, 19 Shimadzu Corp.,), which was connected to the reactor online, equipped with a MICROPACKED ST column using He gas as a carrier. Amount of metal ions in the

21 reaction solution which were eluted from the photocatalyst powder during the 22 photocatalytic reaction was estimated by the elemental analysis using an ICP-OES 23 (iCAP7400 Duo, Thermo Fisher Scientific, Inc.). 


\section{$1 \quad$ Results and discussion}

Figure 1 shows the X-ray diffraction (XRD) patterns of powder samples synthesized via thecoprecipitation method using each of the metal chlorides as precursors $\left(\mathrm{M}^{2+} / \mathrm{M}^{3+}=2\right.$, if not otherwise specified). A series of LDHs $(\mathrm{Co}-\mathrm{Cr}, \mathrm{Co}-\mathrm{Fe}$, $\mathrm{Ni}-\mathrm{V}, \quad \mathrm{Ni}-\mathrm{Cr}, \quad \mathrm{Ni}-\mathrm{Mn}, \quad \mathrm{Ni}-\mathrm{Fe}, \quad \mathrm{Zn}-\mathrm{Cr}, \mathrm{Zn}-\mathrm{Mn}$, and $\mathrm{Zn}-\mathrm{Fe}$ LDH) exhibited characteristic diffraction peaks corresponding to the LDH structure[1], which arepresented as asterisks $(*)$ in Figure 1(a-d). Two sharp diffraction peaks assigned to (003) and (006) phase reflections, were located around $11-12^{\circ}$ and $22-24^{\circ}$, respectively. The broadened (009) phase diffraction peak around $33-35^{\circ}$ was difficult to separate from the (012) phase. The (003), (006), and (009) phase diffraction peaks are related to the structure layered toward the $c$-axis direction. The existence of a layer structure is commonly determined by the reflection peak of the (003) phase. The other two intense peaks around $60-63^{\circ}$, which sometimes occur as a single broad peak, are indexed as (110) and (113) phases with respect to the hexagonal unit. These reflections can be utilized for calculating parameter $a\left(a=2 d_{(110)}\right)$; the value of $a$ depends on the nature of the metal cations of the hydroxide sheets and the ratio of the metal components. These results indicated that $\mathrm{Ni}-\mathrm{M}^{3+}\left(\mathrm{M}^{3+}=\mathrm{V}^{3+}, \mathrm{Cr}^{3+}, \mathrm{Mn}^{3+}\right.$, and $\left.\mathrm{Fe}^{3+}\right), \mathrm{Co}-\mathrm{Cr}, \mathrm{Co}-\mathrm{Fe}$, and $\mathrm{Zn}-\mathrm{Cr}$ LDHs have relatively advanced layer structures along the $c$-axis direction, whereas $\mathrm{Zn}-\mathrm{Mn}$, and $\mathrm{Zn}-\mathrm{Fe} \mathrm{LDHs}$ have layer structures with impurity phases. On the other hand, the other precipitated samples in this study, $\mathrm{Cu}-\mathrm{M}^{3+}\left(\mathrm{M}^{3+}=\mathrm{V}^{3+}, \mathrm{Cr}^{3+}, \mathrm{Mn}^{3+}\right.$, and $\left.\mathrm{Fe}^{3+}\right), \mathrm{Co}-\mathrm{V}, \mathrm{Co}^{-} \mathrm{Mn}$, and $\mathrm{Zn}-\mathrm{V}$, did not form $\mathrm{LDH}$ structures. Diffraction peaks assigned to $\mathrm{Co}_{3} \mathrm{O}_{4}(\diamond)$ werefound in the $\mathrm{Co}-\mathrm{Mn}$ sample, as shown in Figure 1(a). In addition, $\mathrm{CuFeO}_{2}(\bullet)$ and $\mathrm{CuO}(\circ)$ phaseswereconfirmed in the XRD patterns of $\mathrm{Cu}-\mathrm{Fe}$ and $\mathrm{Cu}-\mathrm{Cr}$ precipitates, respectively, which arepresented in Figure 1(c). The impurity 
1 phases, as marked with white triangles $(\nabla)$ and black triangles $(\boldsymbol{\nabla})$ in Figure $\mathbf{1}(\mathbf{d})$,

2 correspond to rhodochrosite $\left(\mathrm{MnCO}_{3}\right)$ and $\mathrm{Zn}_{3}(\mathrm{OH})_{2} \mathrm{~V}_{2} \mathrm{O}_{7} \cdot 2 \mathrm{H}_{2} \mathrm{O}$, respectively. Moreover,

3 the $\mathrm{MnCO}_{3}$ phase reflection $(\nabla)$ wasalso confirmed in the diffraction pattern of $\mathrm{Ni}-\mathrm{Mn}$

$4 \mathrm{LDH}$, as shown in Figure 1(b), indicating that $\mathrm{MnCO}_{3}$ crystalsformedas an impurity

5 phase in the $\mathrm{Ni}-\mathrm{Mn} \mathrm{LDH}$ structure. None of the peaks in the XRD patterns of $\mathrm{Co}-\mathrm{V}$

6 and $\mathrm{Cu}-\mathrm{V}$ precipitates could be assigned to any reported crystal phases.

7 Table 1 summarizes the existence of the LDH structure determined from the XRD

8 patterns, specific surface area $\left(S_{\mathrm{BET}}\right)$, and full width at half maximum of the $(003)$ phase

9 reflection(FWHM $(003))$ for each of the synthesized samples in this study. As mentioned

10 above, the characteristic layer structure of $\mathrm{Co}-\mathrm{Cr}, \mathrm{Co}-\mathrm{Fe}, \mathrm{Ni}-\mathrm{V}, \mathrm{Ni}-\mathrm{Cr}, \mathrm{Ni}-\mathrm{Mn}, \mathrm{Ni}-\mathrm{Fe}$,

$11 \mathrm{Zn}-\mathrm{Cr}, \mathrm{Zn}-\mathrm{Mn}$, and $\mathrm{Zn}-\mathrm{Fe}$ LDHs were confirmed using the XRD patterns. On the

12 other hand, $\mathrm{Co}-\mathrm{V}, \mathrm{Co}-\mathrm{Mn}, \mathrm{Cu}^{-} \mathrm{M}^{3+}\left(\mathrm{M}^{3+}=\mathrm{V}^{3+}, \mathrm{Cr}^{3+}, \mathrm{Mn}^{3+}\right.$, and $\left.\mathrm{Fe}^{3+}\right)$, and $\mathrm{Zn}-\mathrm{V}$

13 precipitates had no LDH structure, although it was previously reported that

$14 \mathrm{Co}-\mathrm{Mn}[11,14], \mathrm{Cu}-\mathrm{Cr}[10]$, and $\mathrm{Cu}-\mathrm{Fe}[19] \mathrm{LDHs}$ were successfully synthesized. In

15 order to achieve the LDHstructure for these precipitates, it is necessary to optimize the

16 detailed preparation procedure, such as the precursor concentration in the solution, the

17 conditions during co-precipitation ( $\mathrm{pH}$, temperature, and atmosphere), and the

18 conditions of aging, rinsing, and drying. In this study, all samples were prepared via a

19 unified procedure, as presented in the experimental section. Among the successfully

20 synthesized LDHs, $\mathrm{Ni}-\mathrm{M}^{3+}\left(\mathrm{M}^{3+}=\mathrm{V}^{3+}, \mathrm{Cr}^{3+}, \mathrm{Mn}^{3+}\right.$, and $\left.\mathrm{Fe}^{3+}\right)$ LDHs exhibited relatively

21 small $\mathrm{FWHM}_{(003)}$ values, indicating that $\mathrm{Ni}-\mathrm{M}^{3+}$ LDHs have anadvanced characteristic

22 layer stacking along the $c$-axis. $\mathrm{Co}-\mathrm{Cr}, \mathrm{Co}-\mathrm{Fe}, \mathrm{Ni}-\mathrm{V}, \mathrm{Zn}-\mathrm{Cr}$, and $\mathrm{Zn}-\mathrm{Fe}$

23 LDHsexhibited particularly large specific surface areas, whereas it was known that the

24 specific surface areas of a series of LDH materials were less than $100 \mathrm{~m}^{2} \mathrm{~g}^{-1}[1,50]$. 
1 Previously, we have reported that $\mathrm{Ni}-\mathrm{Al} \mathrm{LDH}$, which has a large surface area, can

2 produce large amounts of $\mathrm{CO}$ as a reduction product of $\mathrm{CO}_{2}$ in an aqueous solution

3 under UV light irradiation. This indicates that the adsorption of $\mathrm{CO}_{2}$ molecules on the

4 surface of the $\mathrm{Ni}-\mathrm{Al} \mathrm{LDH}$ photocatalyst is asignificant process for the selective

5 conversion of $\mathrm{CO}_{2}$. Table 1 also lists the amounts of products evolved in the gas phase

6 and the selectivity toward $\mathrm{CO}_{2}$ reduction in the photocatalytic conversion of $\mathrm{CO}_{2}$ in an

7 aqueous $\mathrm{NaClsolution}$ using 16 different precipitated samples as photocatalysts for $5 \mathrm{~h}$

8 of photoirradiation. Eachsample showedphotocatalytic activity without pretreatment or

9 modification. Reduction products such as $\mathrm{CO}, \mathrm{CH}_{4}$, and $\mathrm{H}_{2}$ were produced in the gas

10 phase. The photocatalytic activitiespresented in this study didnot correspond with the

11 magnitude of the specific surface areas of the LDH photocatalysts. $\mathrm{Ni}-\mathrm{V} \mathrm{LDH}, \mathrm{Co}-\mathrm{Fe}$

$12 \mathrm{LDH}$, and $\mathrm{Co}^{-} \mathrm{Mn}$ precipitate (no $\mathrm{LDH}$ structure)evolved larger amounts of $\mathrm{CO}$ than

13 that evolved by $\mathrm{Ni}-\mathrm{Al} \mathrm{LDH}$, which was previously reported by our group as a good

14 photocatalyst for this reaction [53]. The amount of $\mathrm{H}_{2}$ producedover these

15 photocatalystsas a reduction product of $\mathrm{H}^{+}$wasless than that of $\mathrm{CO}$, indicating that these

16 photocatalystsachieved a selective reduction of $\mathrm{CO}_{2}$ to $\mathrm{CO}$ and $\mathrm{CH}_{4}$ under $\mathrm{UV}$ light

17 irradiation. In particular, $\mathrm{Ni}-\mathrm{V}$ LDH evolved147.1 $\mu$ molof $\mathrm{CO}$ after $5 \mathrm{~h}$ of

18 photoirradiation, and the selectivity toward $\mathrm{CO}$ formation among the reduction

19 productswas97\%. Moreover, $\mathrm{Co}-\mathrm{Cr} \mathrm{LDH}, \mathrm{Co}-\mathrm{Fe} \mathrm{LDH}, \mathrm{Ni}-\mathrm{Fe} \mathrm{LDH}$, and $\mathrm{Co}-\mathrm{V}$

20 precipitate enabledthe production of a certain amount of $\mathrm{CH}_{4}$, which is known as an

21 eight-electron reduction product of $\mathrm{CO}_{2}$.

22 Figure 2 exhibits the weight loss profiles of $\mathrm{Ni}-\mathrm{M}^{3+}\left(\mathrm{M}^{3+}=\mathrm{V}^{3+}, \mathrm{Cr}^{3+}, \mathrm{Mn}^{3+}\right.$, and

$23 \mathrm{Fe}^{3+}$ ) LDHs measured bythermogravimetric analysis (TGA), which is typically used to

24 characterize the LDH structure in the prepared samples. Several weight losses were 
1 present in the TGA profiles of these as-prepared LDHs. It has been reported that LDHs

2 show characteristic two-step weight losses with increasing temperature[1]. The initial

3 step at $<473 \mathrm{~K}$ was caused by the desorption of water molecules preserved on the

4 surface and in the interlayer. The second step above $473 \mathrm{Kwascaused}$ by the collapse of

5 the layer structure, accompanied by dehydration of the hydroxyl groups and

6 decomposition of the charge compensating interlayer anions. As shown in Figure 2,

$7 \mathrm{Ni}-\mathrm{V}, \mathrm{Ni}-\mathrm{Cr}$, and $\mathrm{Ni}-\mathrm{Fe}$ LDHsexhibitedtwo-step weight loss curves with the increase

8 in temperature.It is expected that the LDH structures of these samples were converted

9 into mixed oxide phases above $700 \mathrm{~K}$. In the case of $\mathrm{Ni}-\mathrm{Mn} \mathrm{LDH}$, however, another

10 weight loss occuredafter the second step. It is presumed that this third weight loss

11 wasdue to the decomposition of $\mathrm{MnCO}_{3}$ into $\mathrm{Mn}_{2} \mathrm{O}_{3}$ [54], indicating that the layer

12 structure of $\mathrm{Ni}-\mathrm{Mn} \mathrm{LDH}$ would collapse at the second step to form $\mathrm{MnCO}_{3}$, and then

13 becamea mixed oxide phase at the third step. The morphologies of the synthesized

$14 \mathrm{Ni}-\mathrm{M}^{3+}\left(\mathrm{M}^{3+}=\mathrm{V}^{3+}, \mathrm{Cr}^{3+}, \mathrm{Mn}^{3+}\right.$, and $\left.\mathrm{Fe}^{3+}\right)$ LDHs were investigated using scanning

15 electron microscopy (SEM) images, as displayed in Figure S1. The assembly of many

16 platelet structures wasobserved in the SEM images of $\mathrm{Ni}-\mathrm{Fe}, \mathrm{Ni}-\mathrm{Mn}$, and $\mathrm{Ni}-\mathrm{V}$ LDHs.

$17 \mathrm{Ni}-\mathrm{Cr} \mathrm{LDH}$ didnot show the sheet structure, although characteristic diffraction peaks

18 due to the layer structure wereclearly confirmed in the XRD pattern. The platelet

19 structure of the $\mathrm{Ni}-\mathrm{V}$ LDH wasmuch smaller than those of the other LDHs, which is

20 consistent with the BET surface area results showing that the $\mathrm{Ni}-\mathrm{V}$ LDH has the largest

21 specific surface area among the $\mathrm{Ni}-\mathrm{M}^{3+}\left(\mathrm{M}^{3+}=\mathrm{V}^{3+}, \mathrm{Cr}^{3+}, \mathrm{Mn}^{3+}\right.$, and $\left.\mathrm{Fe}^{3+}\right)$ LDHs.

$\mathrm{UV} /$ Vis diffuse reflectance spectra of $\mathrm{Ni}-\mathrm{M}^{3+}\left(\mathrm{M}^{3+}=\mathrm{V}^{3+}, \mathrm{Cr}^{3+}, \mathrm{Mn}^{3+}\right.$, and $\left.\mathrm{Fe}^{3+}\right)$

23 LDHs are presented in Figure 3. Absorption peaks due to the d-d transition of $\mathrm{Ni}^{2+}$ and

24 each $\mathrm{M}^{3+}$ were found in the visible region. The photocatalytic reaction did not proceed 
1 thoroughly using a Pyrex jacket equipped with a cooling system, whereas the use of a

2 quartz jacket helped achieve suitable photocatalytic activity. It can be speculated that

3 UV light irradiation $<280 \mathrm{~nm}$ is necessary to induce the photocatalytic reaction over $4 \quad \mathrm{Ni}-\mathrm{M}^{3+}$ LDHs.

Figure 4(a) displays the formation rates of $\mathrm{CO}$ and $\mathrm{H}_{2}$ evolved in the photocatalytic conversion of $\mathrm{CO}_{2}$ in an aqueous NaClsolution after $1 \mathrm{~h}$ of photoirradiation using $\mathrm{Ni}-\mathrm{M}^{3+}\left(\mathrm{M}^{3+}=\mathrm{V}^{3+}, \mathrm{Cr}^{3+}, \mathrm{Mn}^{3+}\right.$, and $\left.\mathrm{Fe}^{3+}\right)$ LDHs, Ni-Al $\mathrm{LDH}$, and $\mathrm{Ni}(\mathrm{OH})_{2}$ as

8 photocatalysts. The amount of $\mathrm{H}_{2}$ evolved wasless than that of $\mathrm{CO}$ in all cases, 9 indicating that selective $\mathrm{CO}_{2}$ reduction was achieved under $\mathrm{UV}$ light irradiation. $\mathrm{Ni}-\mathrm{Cr}$ 10 and $\mathrm{Ni}-\mathrm{Mn}$ LDHs showedlower $\mathrm{CO}$ evolutionactivities thanNi(OH$)_{2}$, which has no 11 characteristic LDH structure. On the other hand, the $\mathrm{CO}$ formation rates for $\mathrm{Ni}-\mathrm{V}$, $12 \mathrm{Ni}-\mathrm{Fe}$, and $\mathrm{Ni}-\mathrm{Al} \mathrm{LDH}$ werehigher thanthat of $\mathrm{Ni}(\mathrm{OH})_{2}$. This result is consistent with 13 the previous assertion that incorporation of $\mathrm{M}^{3+}$ into $\mathrm{Ni}(\mathrm{OH})_{2}$ to construct the $\mathrm{LDH}$ 14 structure clearly enhances the photocatalytic activity for the conversion of $\mathrm{CO}_{2}$ in an 15 aqueous $\mathrm{NaClsolution.} \mathrm{In} \mathrm{particular,} \mathrm{the} \mathrm{CO}$ formation rate over $\mathrm{Ni}-\mathrm{V}$ LDH was49.9 $16 \mu \mathrm{mol} \mathrm{h}{ }^{-1}$ after $1 \mathrm{~h}$ of photoirradiation,which is much greater than that ofthe other $17 \mathrm{Ni}-\mathrm{M}^{3+}\left(\mathrm{M}^{3+}=\mathrm{Cr}^{3+}, \mathrm{Mn}^{3+}, \mathrm{Fe}^{3+}\right.$, and $\left.\mathrm{Al}^{3+}\right)$ LDHs and $\mathrm{Ni}(\mathrm{OH})_{2}$. The time course of the 18 products evolved in the photocatalytic conversion of $\mathrm{CO}_{2}$ in an aqueous NaClsolution using $\mathrm{Ni}-\mathrm{V}$ LDH as a photocatalyst is shown in Figure 4(b). $\mathrm{CO}$ wascontinuously 20 produced as a reduction product of $\mathrm{CO}_{2}$ during the $8 \mathrm{~h}$ of photoirradiation, and the total 21 (accumulated) amount of $\mathrm{CO}$ evolved was $\sim 200 \mu \mathrm{mol}$, whereas the amount of $\mathrm{H}_{2}$ formed 22 was $<10 \mu \mathrm{mol}$. Accordingly, the $\mathrm{Ni}-\mathrm{V} \mathrm{LDH}$ is considered a promising material for the 23 photocatalytic selective conversion of $\mathrm{CO}_{2}$ to $\mathrm{CO}$ in an aqueous NaClsolution. In 24 addition, none of the $\mathrm{Ni}-\mathrm{M}^{3+}\left(\mathrm{M}^{3+}=\mathrm{V}^{3+}, \mathrm{Cr}^{3+}, \mathrm{Mn}^{3+}, \mathrm{Fe}^{3+}\right.$, and $\left.\mathrm{Al}^{3+}\right)$ LDHs showed 
1 photocatalytic activity without $\mathrm{NaCl}$ in the reaction solution. We have previously

2 reported that $\mathrm{Cl}^{-}$in the reaction solution can act as a hole scavenger and improves the

3 photocatalytic conversion of $\mathrm{CO}_{2}$ into $\mathrm{CO}$ over $\mathrm{Ni}-\mathrm{Al}$ LDHphotocatalysts[53]. We

4 presume that $\mathrm{Cl}^{-}$promotes the selective conversion of $\mathrm{CO}_{2}$ for the photocatalytic system

5 using $\mathrm{Ni}-\mathrm{M}^{3+}\left(\mathrm{M}^{3+}=\mathrm{V}^{3+}, \mathrm{Cr}^{3+}, \mathrm{Mn}^{3+}\right.$, and $\left.\mathrm{Fe}^{3+}\right) \mathrm{LDHs}$ via the same mechanism as that

6 of $\mathrm{Ni}-\mathrm{Al} \mathrm{LDH}$.In other words, $\mathrm{Cl}^{-}$is oxidized by the photogenerated holes into $\mathrm{Cl}_{2}$,

7 which is immediately converted into $\mathrm{HClO}$ in water.

8 Figure 5 displays the XRD patterns of (a) $\mathrm{Ni}-\mathrm{V}$ LDH with various $\mathrm{Ni} / \mathrm{V}$ ratios

$9 \quad\left(\mathrm{Ni} / \mathrm{V}=2,3,4\right.$, and 5) and (b) $\mathrm{Ni}_{2}-\mathrm{V}_{x}-\mathrm{Al}_{1-x} \mathrm{LDH}(x=0,0.1,0.5,0.7,1.0)$. The

10 positions of the characteristic diffraction peaks around $11^{\circ}$ (black circle), $23^{\circ}$ (white

11 circle), and $61^{\circ}$ (triangle), which areassigned to the (003), (006), and (110) phase

12 reflections, respectively, didnot alter with the change in the $\mathrm{Ni} / \mathrm{V}$ ratio of $\mathrm{Ni}-\mathrm{V} \mathrm{LDH}$, as

13 shown in Figure 5(a). This result indicates that the hydroxide sheet thickness and the

14 cation to cation distance within the hydroxide sheets is not influenced by the ratio of

$15 \mathrm{Ni}^{2+}$ to $\mathrm{V}^{3+}$ since there is little difference in the reported ionic radii of the 6 -fold 16 coordinated $\mathrm{Ni}^{2+}$ and $\mathrm{V}^{3+}(69.0 \mathrm{pm}$ and $64.0 \mathrm{pm}$, respectively) [55].However, the specific

17 surface areas of the $\mathrm{Ni}-\mathrm{V}$ LDHs wereaffected bythe $\mathrm{Ni} / \mathrm{V}$ ratio within the hydroxide 18 sheets; the observed $S_{\mathrm{BET}}$ values of $\mathrm{Ni} / \mathrm{V}=2,3,4$, and 5 were200, 120, 130, and $87 \mathrm{~m}^{2}$

$19 \mathrm{~g}^{-1}$, respectively. On the other hand, Figure 5(b) shows that the XRD patterns were 20 obviously influencedby the $\mathrm{V} / \mathrm{Al}$ ratio in the $\mathrm{Ni}_{2}-\mathrm{V}_{x}-\mathrm{Al}_{1-x} \mathrm{LDH}$ (the ratio of $\mathrm{Ni} / \mathrm{M}^{3+}$ is 21 fixed at $2, x=0,0.1,0.5,0.7$, and 1.0$)$. The intense peaks $>60^{\circ}$ are attributed to the $(110)$ 22 and (113) phase reflections. These peaks, which sometimes overlap because of 23 broadening, shifted to a higher angle with a decrease in the V/Al ratio. This change can 24 be explained by the incorporation of $\mathrm{Al}^{3+}$, which has a much smaller ionic radii $(53.5$ 
$1 \operatorname{pm}[55])$ than $\mathrm{V}^{3+}$, that decreasesthe average cation-to-cation distance within hydroxide

2 sheets. In addition, the peak intensity and FWHM value of the (003) phase reflection

3 werealtered by the V/Al ratio; the increase in the (003) peak intensity and the decrease

4 in the $\operatorname{FWHM}_{(003)}$ indicated that the layer stacking along the $c$-axis direction

$5 \quad$ wasadvancedby the substitution of $\mathrm{V}^{3+}$ with $\mathrm{Al}^{3+}$ within the hydroxide sheets.

Table 2 displays the amount of products evolved in the photocatalytic conversion of

$7 \quad \mathrm{CO}_{2}$ in an aqueous $\mathrm{NaClsolution}$ using $\mathrm{Ni}-\mathrm{V}$ LDHs with various $\mathrm{Ni} / \mathrm{V}$ ratios, $\mathrm{Ni}(\mathrm{OH})_{2}$,

8 and $\mathrm{V}_{2} \mathrm{O}_{5} . \mathrm{Ni}-\mathrm{V}$ LDHs exhibited much higher $\mathrm{CO}$ formation activities thanNi(OH $)_{2}$ and

$9 \quad \mathrm{~V}_{2} \mathrm{O}_{5}$, which were used as referencephotocatalysts. On the other hand, none of the 10 photocatalysts showed $\mathrm{H}_{2}$ evolution activity via the reduction of $\mathrm{H}_{2} \mathrm{O}$. The $\mathrm{CO}$ formation 11 rate wasclearly affected by the $\mathrm{Ni} / \mathrm{V}$ ratio inthe $\mathrm{Ni}-\mathrm{V} \mathrm{LDH}$, with $\mathrm{Ni} / \mathrm{V}=2$ showingthe 12 largest amount of $\mathrm{CO}$ evolution. The incorporation of $\mathrm{V}^{3+}$ into $\mathrm{Ni}(\mathrm{OH})_{2}$ to construct the 13 LDH structure obviously enhancedthe $\mathrm{CO}$ formation activity. Furthermore, high $\mathrm{V}^{3+}$ 14 content in the $\mathrm{Ni}-\mathrm{V} \mathrm{LDH}$ (which is synonymous with a small $\mathrm{Ni} / \mathrm{V}$ ratio) affordedgood 15 photocatalytic activity for the conversion of $\mathrm{CO}_{2}$ in an aqueous $\mathrm{NaClsolution.} \mathrm{However,}$ 16 the formation rate of $\mathrm{CO}$ gradually decreasedwith the photoirradiation time, and 17 dropped to about a third of the initial rate after $5 \mathrm{~h}$ of photoirradiation. It can be 18 estimated that the $\mathrm{Ni}-\mathrm{V}$ LDH photocatalyst is deactivated during the photocatalytic reaction, as is described later. Figure 6exhibits the $\mathrm{CO}$ formation rate in the photocatalytic conversion of $\mathrm{CO}_{2}$ in an aqueous $\mathrm{NaClsolution}$ using $\mathrm{Ni}_{2}-\mathrm{V}_{x}-\mathrm{Al}_{1-x}$

21 LDHs $(x=0,0.1,0.5,0.7$, and 1.0$)$. The photocatalytic activities wereclearly influenced 22 by the $\mathrm{V}^{3+}$ to $\mathrm{Al}^{3+}$ ratio, and the increase in the $\mathrm{V}^{3+}$ concentration improved theCO 23 formation rate under UV light irradiation. This result is consistent with that of $\mathrm{Ni}-\mathrm{V}$ $24 \mathrm{LDH}$ case; the use of a low $\mathrm{Ni} / \mathrm{V}$ ratio achieved the high photocatalytic activity for 
$1 \mathrm{CO}_{2}$ conversion in an aqueous NaClsolution. The $\mathrm{V}^{3+}$ specie in the $\mathrm{LDH}$ hydroxide

2 sheets is expected to play an important role in this reaction. However, the low $\mathrm{Ni}-\mathrm{V}$

3 LDH stability during the photocatalytic reaction wasnot restituted by the incorporation

4 of $\mathrm{Al}^{3+}$ into the $\mathrm{Ni}-\mathrm{V}$ LDH to assemble the $\mathrm{Ni}_{2}-\mathrm{V}_{x}-\mathrm{Al}_{1-x} \mathrm{LDH}$, which was found to

5 have anrelatively advanced layer structure.

$6 \quad$ Figure 7(a)shows the time course of the products evolved and the amount of metal

7 ions in the reaction solution eluted from the $\mathrm{Ni}-\mathrm{V}$ LDH photocatalyst during the

8 photocatalytic conversion of $\mathrm{CO}_{2}$ in an aqueous $\mathrm{NaClsolution}$. As mentioned previously,

9 the CO formation rate gradually decreasedwith the photoirradiation time:49.9 $\mu \mathrm{mol} \mathrm{h}$

10 after $1 \mathrm{~h}$ of photoirradiationdiminishedto $14.5 \mu \mathrm{mol} \mathrm{h}^{-1}$ after $8 \mathrm{~h}$ of photoirradiation. The

$11 \mathrm{H}_{2}$ formation rate also declinedfrom $1.4 \mu \mathrm{mol} \mathrm{h}^{-1}$ after $1 \mathrm{~h}$ of photoirradiation to 0.3

$12 \mu \mathrm{mol} \mathrm{h}{ }^{-1}$ after $8 \mathrm{~h}$ of photoirradiation. In contrast, the amount of $\mathrm{Ni}$ ions in the reaction

13 solution increasedwith the photocatalytic reaction time. Actually,amorphous

$14 \mathrm{Ni}(\mathrm{OH})_{2}$ wascompletely eluted into the reaction solution within $5 \mathrm{~h}$ of photoirradiation

15 under the same reaction conditions, whereas the $\mathrm{Ni}-\mathrm{Al} \mathrm{LDH}$, which forms a rigid layer

16 structure, wassufficiently stable. Therefore, the pregnable layer structure of the $\mathrm{Ni}-\mathrm{V}$

$17 \mathrm{LDH}$ and the existence of the amorphous $\mathrm{Ni}(\mathrm{OH})_{2}$ phase would facilitate theelution

18 during the photocatalytic reaction.After $8 \mathrm{~h}$ of photoirradiation, partial collapse of the

19 layer structure was found in the XRD patterns, shown in Figure S2, because $\mathrm{FWHM}_{(003)}$

20 was increased as compared with before the photoirradiation.It can be estimated that the

21 non-crystalline phase, e.g., $\mathrm{Ni}(\mathrm{OH})_{2}$ waspreferentially dissolved in the reaction solution.

22 Hence, after $8 \mathrm{~h}$ of photoirradiation, the amount of $\mathrm{V}$ ions in the reaction solution

23 wasmuch lower than that of $\mathrm{Ni}$ ions. As shown in Figure 7(b), which represents an

24 elongated time course, $\mathrm{V}$ ions in the $\mathrm{Ni}-\mathrm{V}$ LDH began elution into the reaction solution 
1 after almost half of the Ni ions have leached out. The formation rates of $\mathrm{CO}$ and $\mathrm{H}_{2}$

2 continuously decreased, and less than $0.3 \mu \mathrm{mol} \mathrm{h}^{-1}$ of $\mathrm{CO}$ wasevolved after $200 \mathrm{~h}$ of

3 photoirradiation.Almost all of the $\mathrm{Ni}-\mathrm{V}$ LDH powder has disappeared during that

4 time; in other words, the powder sample of photocatalyst could not be collected by the

5 filtration of the reaction solution. In addition, the leaching of $\mathrm{Ni}-\mathrm{V}$ LDH wasclearly

6 suppressed under a flow of $\mathrm{He}$ instead of $\mathrm{CO}_{2}$ gas. These results indicated that $\mathrm{Ni}-\mathrm{V}$

7 LDH consisting of mixed hydroxide sheets afforded surface properties suitable for the

8 photocatalytic conversion of $\mathrm{CO}_{2}$ in an aqueous solution; however, this photocatalyst

9 easily leachedunder UV light irradiation in a $\mathrm{CO}_{2}$ atmosphere. When $\mathrm{Ni}-\mathrm{Al} \mathrm{LDH}$ was

10 used as a photocatalyst, as described in previous literature, a stoichiometric amount of

$11 \mathrm{HClO}$ was produced in the reaction solution as an oxidation product of $\mathrm{Cl}^{-}$during the

12 photocatalytic conversion of $\mathrm{CO}_{2}$ in an aqueous NaClsolution [53]. In contrast, the

13 amount of HClOproduced in the photocatalytic reaction using $\mathrm{Ni}-\mathrm{V} \mathrm{LDH}$,

14 asdemonstrated in this study,wasmuch lower than the stoichiometric amount.Although

15 the reason why the incorporation of $\mathrm{V}^{3+}$ enhanced the photocatalytic activity for

$16 \mathrm{CO}_{2}$ conversion is stillnot clear, we estimate the oxidation reaction pass as presented

17 below.

(1) $2 \mathrm{Cl}^{-}+2 \mathrm{~h}^{+} \rightarrow \mathrm{Cl}_{2}$

(2) $\mathrm{Cl}_{2}+\mathrm{H}_{2} \mathrm{O} \rightarrow \mathrm{HClO}+\mathrm{HCl}$

(3) $2 \mathrm{HClO}+2 \mathrm{H}^{+}+2 \mathrm{e}^{-} \rightarrow \mathrm{Cl}_{2}+2 \mathrm{H}_{2} \mathrm{O}$

(4) $\mathrm{V}^{3+}+\mathrm{H}_{2} \mathrm{O} \rightarrow \mathrm{VO}^{2+}+2 \mathrm{H}^{+}+\mathrm{e}^{-}$

$22 \mathrm{Cl}^{-}$was oxidized to chlorine $\left(\mathrm{Cl}_{2}\right)$ by capturing the photogenerated holes, as shown in

23 formula (1). This reaction is considered to trigger the subsequent process, because the

24 photocatalytic activity of $\mathrm{Ni}-\mathrm{V}$ LDH is completely diminished in the absence of $\mathrm{NaCl}$.It 
1 is known that $\mathrm{Cl}_{2}$ isimmediately converted to $\mathrm{HClO}$ and $\mathrm{HCl}$ via

2 disproportionationreaction in water (formula (2)). It can be approximated that $\mathrm{HCl}$

3 produced in the reaction solutionby the disproportionation of HClOcauses $\mathrm{Ni}-\mathrm{V}$ LDH

4 to be more easily leached. Meanwhile, $\mathrm{HClO}$ has strong oxidation power due to the

5 reaction shown in formula (3), according to the reported value of $E^{\circ}\left(\mathrm{HClO} / \mathrm{Cl}_{2}\right)=1.630$

6 V vs. SHE[56], indicating that $\mathrm{HClO}$ can oxidize the $\mathrm{V}^{3+}$ present in the hydroxide sheets

7 and/or in the reaction solution. Considering the oxidation potential from $\mathrm{V}^{3+}$ to

$8 \mathrm{VO}^{2+}\left(E^{\circ}\left(\mathrm{VO}^{2+} / \mathrm{V}^{3+}\right)=0.337 \mathrm{~V}\right.$ vs. SHE[56]), the wholeformula forHClOconsumption in

9 the reaction solution can be described byformula (5).

(5) $2 \mathrm{HClO}+2 \mathrm{~V}^{3+} \rightarrow \mathrm{Cl}_{2}+2 \mathrm{VO}^{2+}+2 \mathrm{H}^{+}$

$11 \mathrm{VO}^{2+}$ is sufficiently soluble and showslight blue color in aqueous solution. The filtrate 12 solution after the photocatalytic reaction actuallyexhibited a slightly blue color. The 13 reason why $\mathrm{HClO}$, which was considered to be an oxidation product of $\mathrm{Cl}^{-}$, was not 14 detected at all by DPD testis that HClOproduced in the reaction solution 15 wascontinuously consumed by $\mathrm{V}^{3+}$ species. Unfortunately, quantitative balance between 16 consumed electrons and holes could not be estimated because amount of the final 17 product of oxidation reactions (maybe $\mathrm{VO}^{2+}$ ) were not quantified 18 experimentally.Regeneration of $\mathrm{Cl}_{2}$ via the oxidation of $\mathrm{V}^{3+}$ (formula (5))is considered to be converted to $\mathrm{HClO}$ and HClagain, as shown in formula (2), indicating that a combination of $\mathrm{V}^{3+}$ and $\mathrm{Cl}^{-}$might plays significant roleslike a redox couple in the

21 consumption of photogenerated holes during the photocatalytic conversion of $\mathrm{CO}_{2}$ into $22 \mathrm{CO}$. Therefore, the incorporation of $\mathrm{V} 3+$ into the LDH structure made the consumption 23 of photogenerated electronsOn the other hand, the addition of $\mathrm{Na}_{2} \mathrm{CO}_{3}$ to the reaction 24 solution as a second additive $\left(0.1 \mathrm{M} \mathrm{NaCl}+0.1 \mathrm{M} \mathrm{Na}_{2} \mathrm{CO}_{3}\right)$ improvedthe stability of the 
$1 \mathrm{Ni}-\mathrm{V}$ LDH photocatalyst for the conversion of $\mathrm{CO}_{2}$ to $\mathrm{CO}$ in an aqueous solution, as 2 shown in Figure 8. The increase of $\mathrm{pH}$ from 5.0 to 7.0 by adding $\mathrm{Na}_{2} \mathrm{CO}_{3}$ to the aqueous

3 NaClsolution effectively suppressedthe leaching of $\mathrm{Ni}-\mathrm{V}$ LDH during the 4 photocatalytic reaction. We conclude that the $\mathrm{Ni}-\mathrm{V}$ LDH photocatalyst is substantially 5 active for the conversion of $\mathrm{CO}_{2}$ in an aqueous NaClsolution, though its stability under 6 the reaction conditions is insufficient because of the oxidation of $\mathrm{V}^{3+}$ induced by $\mathrm{HClO}$. 7 The co-presence of $\mathrm{V}^{3+}$ and $\mathrm{Cl}^{-}$might make it possible to achieve high photocatalytic 8 activity for the conversion of $\mathrm{CO}_{2}$ into $\mathrm{CO}$ in an aqueous solution. 


\section{Conclusion}

2 We found that $\mathrm{Ni}-\mathrm{V}$ LDHshowed the high photocatalytic activity for the

3 conversion of $\mathrm{CO}_{2}$ in an aqueous solution of $\mathrm{NaCl}$. Over $200 \mu \mathrm{mol}$ of $\mathrm{CO}$ was evolved

4 as a reduction product of $\mathrm{CO}_{2}$ after $8 \mathrm{~h}$ of photoirradiation when $\mathrm{Ni}-\mathrm{V} \mathrm{LDH}(\mathrm{Ni} / \mathrm{V}=2)$

5 was used as a photocatalyst.Through the investigation of photocatalytic activities for

6 different $\mathrm{V}^{3+}$ content of $\mathrm{Ni}-\mathrm{V}$ LDH and $\mathrm{Ni}-\mathrm{V}-\mathrm{Al} \mathrm{LDH}$, the existence of $\mathrm{V}^{3+}$ afforded

7 good performance for the conversion of $\mathrm{CO}_{2}$ into $\mathrm{CO}$ in an aqueous solution of $\mathrm{NaCl}$.

8 The stability of $\mathrm{Ni}-\mathrm{V}$ LDH was insufficient due to the leaching into the reaction

9 solution. It can be noted that the combination of $\mathrm{V}^{3+}$ and $\mathrm{Cl}^{-}$play a significant role in

10 the photocatalytic conversion of $\mathrm{CO}_{2}$ to $\mathrm{CO}$ in an aqueous solution. 


\section{Acknowledgement}

2 This study was partially supported by a Grant-in-Aid for Scientific Research on

3 Innovative Areas "All Nippon Artificial Photosynthesis Project for Living Earth" (No.

4 2406) of the Ministry of Education, Culture, Sports, Science, and Technology (MEXT)

5 of Japan, the Precursory Research for Embryonic Science and Technology (PRESTO),

6 supported by the Japan Science and Technology Agency (JST), and the Program for

7 Element Strategy Initiative for Catalysts \& Batteries (ESICB), commissioned by the

8 MEXT of Japan. Shoji Iguchi thanks the JSPS Research Fellowships for Young

9 Scientists. 


\section{$1 \quad$ References}

2 [1] F. Cavani, F. Trifirò, A. Vaccari, Hydrotalcite-type anionic clays: Preparation, 3 properties and applications, Catalysis Today, 11 (1991) 173-301.

4 [2] C. Delhoyo, Layered double hydroxides and human health: An overview, Applied $5 \quad$ Clay Science, 36 (2007) 103-121.

6 [3] Z.P. Xu, J. Zhang, M.O. Adebajo, H. Zhang, C. Zhou, Catalytic applications of 7 layered double hydroxides and derivatives, Applied Clay Science, 53 (2011) 139-150.

8 [4] B. Li, Y. Zhao, S. Zhang, W. Gao, M. Wei, Visible-light-responsive photocatalysts

9 toward water oxidation based on NiTi-layered double hydroxide/reduced graphene 10 oxide composite materials, ACS Appl Mater Interfaces, 5 (2013) 10233-10239.

11 [5] X. Zhang, Z. Wang, N. Qiao, S. Qu, Z. Hao, Selective Catalytic Oxidation of $\mathrm{H}_{2} \mathrm{~S}$ 12 over Well-Mixed Oxides Derived from $\mathrm{Mg}_{2} \mathrm{Al}_{x} \mathrm{~V}_{1-x}$ Layered Double Hydroxides, ACS 13 Catalysis, 4 (2014) 1500-1510.

14 [6] J. Prince, F. Tzompantzi, G. Mendoza-Damián, F. Hernández-Beltrán, J.S. Valente, 15 Photocatalytic degradation of phenol by semiconducting mixed oxides derived from $16 \mathrm{Zn}(\mathrm{Ga}) \mathrm{Al}$ layered double hydroxides, Applied Catalysis B: Environmental, 163 (2015) $17 \quad 352-360$.

18 [7] X. Xu, R. Lu, X. Zhao, S. Xu, X. Lei, F. Zhang, D.G. Evans, Fabrication and 19 photocatalytic performance of a $\mathrm{Zn}_{x} \mathrm{Cd}_{1-x} \mathrm{~S}$ solid solution prepared by sulfuration of a 20 single layered double hydroxide precursor, Applied Catalysis B: Environmental, 102 21 (2011) 147-156.

22 [8] T. Iwasaki, H. Yoshii, H. Nakamura, S. Watano, Simple and rapid synthesis of Ni-Fe 23 layered double hydroxide by a new mechanochemical method, Applied Clay Science, $2458(2012) 120-124$. 
1 [9] L. Huang, S. Chu, J. Wang, F. Kong, L. Luo, Y. Wang, Z. Zou, Novel visible light

2 driven $\mathrm{Mg}-\mathrm{Zn}$-In ternary layered materials for photocatalytic degradation of methylene

3 blue, Catalysis Today, 212 (2013) 81-88.

4 [10] L. Tian, Y. Zhao, S. He, M. Wei, X. Duan, Immobilized Cu-Cr layered double

5 hydroxide films with visible-light responsive photocatalysis for organic pollutants,

6 Chemical Engineering Journal, 184 (2012) 261-267.

7 [11] H. Lin, Y. Zhang, G. Wang, J.-B. Li, Cobalt-based layered double hydroxides as

8 oxygen evolving electrocatalysts in neutral electrolyte, Frontiers of Materials Science, 6

$9 \quad$ (2012) 142-148.

10 [12] G. Abellan, E. Coronado, C. Marti-Gastaldo, J. Waerenborgh, A. Ribera, Interplay

11 between chemical composition and cation ordering in the magnetism of $\mathrm{Ni} / \mathrm{Fe}$ layered 12 double hydroxides, InorgChem, 52 (2013) 10147-10157.

13 [13] M. Gong, Y. Li, H. Wang, Y. Liang, J.Z. Wu, J. Zhou, J. Wang, T. Regier, F. Wei, H.

14 Dai, An advanced Ni-Fe layered double hydroxide electrocatalyst for water oxidation, J

15 Am ChemSoc, 135 (2013) 8452-8455.

16 [14] F. Song, X. Hu, Ultrathin cobalt-manganese layered double hydroxide is an

17 efficient oxygen evolution catalyst, J Am ChemSoc, 136 (2014) 16481-16484.

18 [15] F.B. Saiah, B.L. Su, N. Bettahar, Nickel-iron layered double hydroxide (LDH):

19 textural properties upon hydrothermal treatments and application on dye sorption, J

20 Hazard Mater, 165 (2009) 206-217.

21 [16] T. Takei, A. Miura, N. Kumada, K. Okada, Soft-chemical treatment of 22 transition-metal-containing layered double hydroxides and their application in porous 23 materials, Journal of Porous Materials, 20 (2012) 777-783.

24 [17] F. Giovannelli, M. Zaghrioui, C. Autret-Lambert, F. Delorme, A. Seron, T. Chartier, 
1 B. Pignon, Magnetic properties of $\mathrm{Ni}(\mathrm{II})-\mathrm{Mn}(\mathrm{III})$ LDHs, Materials Chemistry and 2 Physics, 137 (2012) 55-60.

3 [18] C.G. Silva, Y. Bouizi, V. Fornés, H. García, Layered Double Hydroxides as Highly

4 Efficient Photocatalysts for Visible Light Oxygen Generation from Water, Journal of the

5 American Chemical Society, 131 (2009) 13833-13839.

6 [19] Y. Guo, Z. Zhu, Y. Qiu, J. Zhao, Adsorption of arsenate on $\mathrm{Cu} / \mathrm{Mg} / \mathrm{Fe} / \mathrm{La}$ layered

7 double hydroxide from aqueous solutions, Journal of Hazardous Materials, 239-240

$8 \quad$ (2012) 279-288.

9 [20] J.M. Fernández, C. Barriga, M.A. Ulibarri, F.M. Labajos, V. Rives, New 10 Hydrotalcite-like Compounds Containing Yttrium, Chemistry of Materials, 9 (1997) $11 \quad 312-318$.

12 [21] E.M. Seftel, E. Popovici, M. Mertens, E.A. Stefaniak, R. Van Grieken, P. Cool, E.F. 13 Vansant, SnIV-containing layered double hydroxides as precursors for nano-sized $14 \mathrm{ZnO} / \mathrm{SnO}_{2}$ photocatalysts, Applied Catalysis B: Environmental, 84 (2008) 699-705.

15 [22] S.-J. Xia, F.-X.Liu, Z.-M.Ni, W. Shi, J.-L.Xue, P.-P. Qian, Ti-based layered double 16 hydroxides: Efficient photocatalysts for azo dyes degradation under visible light, 17 Applied Catalysis B: Environmental, 144 (2014) 570-579.

18 [23] X. Wang, P. Wu, Z. Huang, N. Zhu, J. Wu, P. Li, Z. Dang, Solar photocatalytic 19 degradation of methylene blue by mixed metal oxide catalysts derived from ZnAlTi 20 layered double hydroxides, Applied Clay Science, 95 (2014) 95-103.

21 [24] G. Chen, S. Qian, X. Tu, X. Wei, J. Zou, L. Leng, S. Luo, Enhancement 22 photocatalytic degradation of rhodamine B on nanoPt intercalated $\mathrm{Zn}$-Ti layered double 23 hydroxides, Applied Surface Science, 293 (2014) 345-351.

24 [25] M. Shao, J. Han, M. Wei, D.G. Evans, X. Duan, The synthesis of hierarchical 
$1 \mathrm{Zn}-\mathrm{Ti}$ layered double hydroxide for efficient visible-light photocatalysis, Chemical

$2 \quad$ Engineering Journal, 168 (2011) 519-524.

3 [26] Y. Zhao, P. Chen, B. Zhang, D.S. Su, S. Zhang, L. Tian, J. Lu, Z. Li, X. Cao, B.

4 Wang, M. Wei, D.G. Evans, X. Duan, Highly dispersed $\mathrm{TiO}_{6}$ units in a layered double

$5 \quad$ hydroxide for water splitting, Chemistry, 18 (2012) 11949-11958.

6 [27] O. Saber, Preparation and characterization of a new nano layered material, $\mathrm{Co}-\mathrm{Zr}$

7 LDH, Journal of Materials Science, 42 (2007) 9905-9912.

8 [28] X. Shu, W. Zhang, J. He, F. Gao, Y. Zhu, Formation of Ni-Ti-layered double

9 hydroxides using homogeneous precipitation method, Solid State Sciences, 8 (2006) $10 \quad 634-639$.

11 [29] S.J. Xia, F.X. Liu, Z.M. Ni, J.L. Xue, P.P. Qian, Layered double hydroxides as 12 efficient photocatalysts for visible-light degradation of Rhodamine B, J Colloid 13 Interface Sci, 405 (2013) 195-200.

14 [30] L. Mohapatra, K.M. Parida, $\mathrm{Zn}-\mathrm{Cr}$ layered double hydroxide: Visible light 15 responsive photocatalyst for photocatalytic degradation of organic pollutants, 16 Separation and Purification Technology, 91 (2012) 73-80.

17 [31] J. Sun, Y. Zhang, J. Cheng, H. Fan, J. Zhu, X. Wang, S. Ai, Synthesis of $18 \mathrm{Ag} / \mathrm{AgCl} / \mathrm{Zn}-\mathrm{Cr}$ LDHs composite with enhanced visible-light photocatalytic 19 performance, Journal of Molecular Catalysis A: Chemical, 382 (2014) 146-153.

20 [32] L. Mohapatra, K.M. Parida, Dramatic activities of vanadate intercalated bismuth 21 doped LDH for solar light photocatalysis, Phys ChemChem Phys, 16 (2014) 22 16985-16996.

23 [33] J.S. Valente, F. Tzompantzi, J. Prince, Highly efficient photocatalytic elimination of 24 phenol and chlorinated phenols by $\mathrm{CeO}_{2} / \mathrm{MgAl}$ layered double hydroxides, Applied 
1 Catalysis B: Environmental, 102 (2011) 276-285.

2 [34] S. Pausova, J. Krysa, J. Jirkovsky, G. Mailhot, V. Prevot, Photocatalytic behavior of

3 nanosized $\mathrm{TiO}_{2}$ immobilized on layered double hydroxides by delamination/restacking

4 process, Environ SciPollut Res Int, 19 (2012) 3709-3718.

5 [35] S. Yuan, Y. Li, Q. Zhang, H. Wang, ZnOnanorods decorated calcined Mg-Al

6 layered double hydroxides as photocatalysts with a high adsorptive capacity, Colloids

7 and Surfaces A: Physicochemical and Engineering Aspects, 348 (2009) 76-81.

8 [36] E. Dvininov, M. Ignat, P. Barvinschi, M.A. Smithers, E. Popovici, New

$9 \quad \mathrm{SnO}_{2} / \mathrm{MgAl}$-layered double hydroxide composites as photocatalysts for cationic dyes 10 bleaching, J Hazard Mater, 177 (2010) 150-158.

11 [37] D. Chen, Y. Li, J. Zhang, J.-z. Zhou, Y. Guo, H. Liu, Magnetic $\mathrm{Fe}_{3} \mathrm{O}_{4} / \mathrm{ZnCr-layered}$ 12 double hydroxide composite with enhanced adsorption and photocatalytic activity, 13 Chemical Engineering Journal, 185-186 (2012) 120-126.

14 [38] Y. Kohno, T. Tanaka, T. Funabiki, S. Yoshida, Photoreduction of carbon dioxide 15 with hydrogen over $\mathrm{ZrO}_{2}$, Chemical Communications, (1997) 841-842.

16 [39] Y. Kohno, T. tanaka, T. Funabiki, S. Yoshida, Photoreduction of Carbon Dioxide 17 with Methane over $\mathrm{ZrO}_{2}$, Chemistry Letters, 26 (1997) 993-994.

18 [40] Y. Kohno, T. Tanaka, T. Funabiki, S. Yoshida, Identification and reactivity of a 19 surface intermediate in the photoreduction of $\mathrm{CO}_{2}$ with $\mathrm{H}_{2}$ over $\mathrm{ZrO}_{2}$, Journal of the 20 Chemical Society, Faraday Transactions, 94 (1998) 1875-1880.

21 [41] Y. Kohno, T. Tanaka, T. Funabiki, S. Yoshida, Photoreduction of $\mathrm{CO}_{2}$ with $\mathrm{H}_{2}$ over $22 \mathrm{ZrO}_{2}$. A study on interaction of hydrogen with photoexcited $\mathrm{CO}_{2}$, Physical Chemistry 23 Chemical Physics, 2 (2000) 2635-2639.

24 [42] Y. Kohno, H. Ishikawa, T. Tanaka, T. Funabiki, S. Yoshida, Photoreduction of 
1 carbon dioxide by hydrogen over magnesium oxide, Physical Chemistry Chemical

2 Physics, 3 (2001) 1108-1113.

3 [43] K. Teramura, T. Tanaka, H. Ishikawa, Y. Kohno, T. Funabiki, Photocatalytic

4 Reduction of $\mathrm{CO}_{2}$ to $\mathrm{CO}$ in the Presence of $\mathrm{H}_{2}$ or $\mathrm{CH}_{4}$ as a Reductant over $\mathrm{MgO}$, The

$5 \quad$ Journal of Physical Chemistry B, 108 (2004) 346-354.

6 [44] H. Tsuneoka, K. Teramura, T. Shishido, T. Tanaka, Adsorbed Species of $\mathrm{CO}_{2}$ and

$7 \mathrm{H}_{2}$ on $\mathrm{Ga}_{2} \mathrm{O}_{3}$ for the Photocatalytic Reduction of $\mathrm{CO}_{2}$, The Journal of Physical

8 Chemistry C, 114 (2010) 8892-8898.

9 [45] K. Teramura, S. Iguchi, Y. Mizuno, T. Shishido, T. Tanaka, Photocatalytic 10 conversion of $\mathrm{CO}_{2}$ in water over layered double hydroxides, AngewChemInt Ed Engl, $1151(2012) 8008-8011$.

12 [46] N. Ahmed, Y. Shibata, T. Taniguchi, Y. Izumi, Photocatalytic conversion of carbon 13 dioxide into methanol using zinc-copper-M(III) ( $\mathrm{M}=$ aluminum, gallium) layered 14 double hydroxides, Journal of Catalysis, 279 (2011) 123-135.

15 [47] M. Morikawa, N. Ahmed, Y. Yoshida, Y. Izumi, Photoconversion of carbon dioxide 16 in zinc-copper-gallium layered double hydroxides: The kinetics to hydrogen carbonate 17 and further to CO/methanol, Applied Catalysis B: Environmental, 144 (2014) 561-569.

18 [48] M. Morikawa, Y. Ogura, N. Ahmed, S. Kawamura, G. Mikami, S. Okamoto, Y. 19 Izumi, Photocatalytic conversion of carbon dioxide into methanol in reverse fuel cells 20 with tungsten oxide and layered double hydroxide photocatalysts for solar fuel 21 generation, Catal. Sci. Technol., 4 (2014) 1644-1651.

22 [49] K.-i. Katsumata, K. Sakai, K. Ikeda, G. Carja, N. Matsushita, K. Okada, 23 Preparation and photocatalytic reduction of $\mathrm{CO}_{2}$ on noble metal ( $\left.\mathrm{Pt}, \mathrm{Pd}, \mathrm{Au}\right)$ loaded 24 Zn-Cr layered double hydroxides, Materials Letters, 107 (2013) 138-140. 
1 [50] S. Iguchi, K. Teramura, S. Hosokawa, T. Tanaka, Photocatalytic conversion of $\mathrm{CO}_{2}$

2 in an aqueous solution using various kinds of layered double hydroxides, Catalysis

3 Today, 251 (2015) 140-144.

4 [51] K. Carlsson, L. Moberg, B. Karlberg, The miniaturisation of the standard method

5 based on the N,N'-diethyl-p-phenylenediamine (DPD) reagent for the determination of

6 free or combined chlorine, Water Research, 33 (1999) 375-380.

7 [52] L. Moberg, B. Karlberg, An improved N,N'-diethyl-p-phenylenediamine (DPD)

8 method for the determination of free chlorine based on multiple wavelength detection,

$9 \quad$ AnalyticaChimicaActa, 407 (2000) 127-133.

10 [53] S. Iguchi, K. Teramura, S. Hosokawa, T. Tanaka, Effect of the chloride ion as a

11 hole scavenger on the photocatalytic conversion of $\mathrm{CO}_{2}$ in an aqueous solution over

12 Ni-Al layered double hydroxides, Phys ChemChem Phys, 17 (2015) 17995-18003.

13 [54] Lianyi Shao, Jie Shu, Rui Ma, Miao Shui, Lu Hou, Kaiqiang Wu, Dongjie Wang, Y.

14 Ren, Electrochemical Characteristics and Intercalation Mechanism of

15 Manganese Carbonate as Anode Material for Lithium-Ion

16 Batteries, International Journal of Electrochemical Science, 8 (2013) 1170-1180.

17 [55] R.D. Shannon, Revised effective ionic radii and systematic studies of interatomic

18 distances in halides and chalcogenides, ActaCrystallographica Section A, 32 (1976)

$19 \quad 751-767$.

20 [56] A.J. Bard, R. Parsons, J. Jordan, Eds., Standard Potentials in Aqueous Solution, 21 Marcel Dekker (1985). 
1 Table 1 Summary of the characterizations and the photocatalytic activity test for the 2 synthesized 16 different kinds of $\mathrm{M}^{2+}-\mathrm{M}^{3+} \mathrm{LDHs}\left(\mathrm{M}^{2+}=\mathrm{Co}^{2+}, \mathrm{Ni}^{2+}, \mathrm{Cu}^{2+}\right.$, and $\mathrm{Zn}^{2+}$;

$3 \quad \mathrm{M}^{3+}=\mathrm{V}^{3+}, \mathrm{Cr}^{3+}, \mathrm{Mn}^{3+}$, and $\left.\mathrm{Fe}^{3+}\right) .{ }^{a} \mathrm{LDH}$ structure was judged from the XRD patterns.

$4{ }^{b} S_{\mathrm{BET}}$ was estimated from the $\mathrm{N}_{2}$ absorption isotherms at $77 \mathrm{~K} .{ }^{c}$ Amounts of products

5 evolved were evaluated by the photocatalytic reaction; photocatalyst weight $500 \mathrm{mg}$,

6 water $1.0 \mathrm{~L}$, additive $0.1 \mathrm{M} \mathrm{NaCl}, \mathrm{CO}_{2}$ supply $15 \mathrm{~mL} \mathrm{~min}^{-1}$, light source $400 \mathrm{~W}$

7 high-pressure $\mathrm{Hg}$ lamp. ${ }^{d}$ Selectivity to $\mathrm{CO}_{2}$ reduction was calculated by using the

8 formula; Selectivity to $\mathrm{CO}_{2}$ reduction $(\%)=100 \times\left(\left(\mathrm{CO}+\mathrm{CH}_{4}\right) /\left(\mathrm{CO}+\mathrm{CH}_{4}+\mathrm{H}_{2}\right)\right)$.

9

\begin{tabular}{|c|c|c|c|c|c|c|c|c|}
\hline \multicolumn{2}{|c|}{ Components } & \multirow{2}{*}{$\begin{array}{c}{ }^{a} \mathrm{LDH} \\
\text { structure }\end{array}$} & \multirow{2}{*}{$\begin{array}{l}{ }^{b} \mathrm{SBET}_{\mathrm{BET}} \\
/ \mathrm{m}^{-} \mathrm{g}^{-1}\end{array}$} & \multirow{2}{*}{$\begin{array}{c}\text { FWHM }_{(003)} \\
\text { / degree }\end{array}$} & \multicolumn{3}{|c|}{${ }^{c}$ Amounts of products evolved / $\mu \mathrm{mol}$} & \multirow{2}{*}{$\begin{array}{l}{ }^{d} \text { Selectivity to } \mathrm{CO}_{2} \text { reduction } \\
(\%)\end{array}$} \\
\hline divalent & trivalent & & & & $\mathrm{CO}$ & $\mathrm{CH}_{4}$ & $\mathrm{H}_{2}$ & \\
\hline \multirow[t]{4}{*}{ Co } & $\mathrm{V}$ & - & 12 & - & 3.3 & 1.4 & 0.2 & 96 \\
\hline & $\mathrm{Cr}$ & 0 & 140 & 3.1 & 40.2 & 1.0 & 3.0 & 93 \\
\hline & $\mathrm{Mn}$ & - & 52 & - & 59.8 & trace & 2.0 & 97 \\
\hline & $\mathrm{Fe}$ & 0 & 110 & 0.6 & 109.1 & 5.2 & 6.6 & 95 \\
\hline \multirow[t]{4}{*}{$\mathrm{Ni}$} & $\mathrm{V}$ & 0 & 200 & 2.2 & 147.1 & trace & 4.2 & 97 \\
\hline & $\mathrm{Cr}$ & O & 75 & 1.1 & 4.6 & 0.0 & 2.8 & 62 \\
\hline & $\mathrm{Mn}$ & O & 27 & 0.6 & 4.6 & 0.0 & 17.0 & 21 \\
\hline & $\mathrm{Fe}$ & 0 & 30 & 0.9 & 29.0 & 1.3 & 7.9 & 79 \\
\hline \multirow[t]{4}{*}{$\mathrm{Cu}$} & V & - & 48 & - & 9.4 & 0.0 & 4.3 & 69 \\
\hline & $\mathrm{Cr}$ & - & 60 & - & 2.0 & trace & 4.1 & 33 \\
\hline & $\mathrm{Mn}$ & - & 39 & - & 2.4 & 0.0 & 0.2 & 92 \\
\hline & $\mathrm{Fe}$ & - & 55 & - & 5.3 & 0.0 & 0.8 & 87 \\
\hline \multirow[t]{4}{*}{$\mathrm{Zn}$} & $\mathrm{V}$ & - & 70 & - & 3.8 & 0.0 & 0.0 & 100 \\
\hline & $\mathrm{Cr}$ & 0 & 260 & 1.7 & 34.0 & 0.0 & 7.1 & 83 \\
\hline & $\mathrm{Mn}$ & 0 & 81 & 2.5 & 24.0 & 0.0 & 30.0 & 44 \\
\hline & $\mathrm{Fe}$ & 0 & 140 & - & 3.3 & 0.0 & 27.0 & 11 \\
\hline
\end{tabular}


1 Table 2 Formation rates of products evolved in the photocatalytic conversion of $2 \mathrm{CO}_{2}$ in an aqueous solution of $\mathrm{NaCl}$ using $\mathrm{Ni}-\mathrm{V}$ LDHs with various $\mathrm{Ni} / \mathrm{V}$ ratio after $1 \mathrm{~h}$ 3 and $5 \mathrm{~h}$ of photoirradiation. Photocatalyst weight $500 \mathrm{mg}$, water $1.0 \mathrm{~L}$, additive $0.1 \mathrm{M}$ $4 \mathrm{NaCl}, \mathrm{CO}_{2}$ supply $15 \mathrm{~mL} \mathrm{~min}^{-1}$, light source $400 \mathrm{~W}$ high-pressure Hg lamp. 5

\begin{tabular}{cccccc}
\hline & \multicolumn{5}{c}{ Formation rate $/ \mu \mathrm{mol} \mathrm{h}^{-1}$} \\
\cline { 2 - 3 } \cline { 5 - 6 } \cline { 5 - 6 } \cline { 5 - 6 } & \multicolumn{3}{c}{$\mathrm{CO}$} & & \multicolumn{3}{c}{$\mathrm{H}_{2}$} \\
\cline { 2 - 3 } \cline { 5 - 6 }$/ \mathrm{h}=2$ & 49.9 & 16.5 & & 1.4 & 0.5 \\
$\mathrm{Ni} / \mathrm{V}=3$ & 23.0 & 7.6 & & 1.3 & 0.2 \\
$\mathrm{Ni} / \mathrm{V}=4$ & 15.6 & 4.6 & & 0.9 & 0.1 \\
$\mathrm{Ni} / \mathrm{V}=5$ & 12.9 & 8.4 & & 0.0 & 0.1 \\
\hline $\mathrm{Ni}(\mathrm{OH})_{2}$ & 3.1 & 4.6 & & 1.1 & 0.5 \\
$\mathrm{~V}_{2} \mathrm{O}_{5}$ & 0.2 & Trace & & Trace & Trace \\
\hline
\end{tabular}

6 7 


\section{$1 \quad$ Figure captions}

2 Figure 1 XRD patterns of (a) $\mathrm{Co}^{-}-\mathrm{M}^{3+} \mathrm{LDHs}$, (b) $\mathrm{Ni}-\mathrm{M}^{3+} \mathrm{LDHs}$, (c) $\mathrm{Cu}-\mathrm{M}^{3+}$

3 LDHs, and (d) $\mathrm{Zn}-\mathrm{M}^{3+}$ LDHs. $\mathrm{M}^{3+}=\mathrm{V}^{3+}, \mathrm{Cr}^{3+}, \mathrm{Mn}^{3+}$, and $\mathrm{Fe}^{3+}$ are given as (i), (ii), (iii),

4 and (iv) in the figures, respectively. The characteristic peaks are marked with asterisk

$5 \quad(*)$, diamond $(\diamond)$, white triangle $(\Delta)$, black circle $(\bullet)$, white circle $(\circ)$, and black triangle

$6(\boldsymbol{\nabla})$, which are respectively assigned to $\mathrm{LDH}$ structure, $\mathrm{Co}_{3} \mathrm{O}_{4}$, rhodochrosite $\left(\mathrm{MnCO}_{3}\right)$,

$7 \quad \mathrm{CuFeO}_{2}, \mathrm{CuO}$, and $\mathrm{Zn}_{3}(\mathrm{OH})_{2} \mathrm{~V}_{2} \mathrm{O}_{7} \cdot 2 \mathrm{H}_{2} \mathrm{O}$.

8 Figure 2 Weight loss profiles of $\mathrm{Ni}-\mathrm{M}^{3+} \mathrm{LDHs}\left(\mathrm{M}^{3+}=(\mathrm{i}) \mathrm{V}^{3+}\right.$, (ii) $\mathrm{Cr}^{3+}$, (iii) $\mathrm{Mn}^{3+}$,

9 and (iv) $\mathrm{Fe}^{3+}$ ) in a thermal gravimetric analysis. Atmosphere: dried air flow at a rate of $1080 \mathrm{~mL} \mathrm{~min}^{-1}$, temperature increasing rate: $5 \mathrm{~K} \mathrm{~min}^{-1}$.

11 Figure 3 UV/Vis diffuse reflectance spectra of $\mathrm{Ni}-\mathrm{M}^{3+} \mathrm{LDHs}\left(\mathrm{M}^{3+}=\right.$ (i) $\mathrm{V}^{3+}$, (ii) $12 \mathrm{Cr}^{3+}$, (iii) $\mathrm{Mn}^{3+}$, and (iv) $\mathrm{Fe}^{3+}$ ).

13 Figure 4(a) Formation rates of $\mathrm{CO}$ (red bar) and $\mathrm{H}_{2}$ (blue bar) evolved in the 14 photocatalytic conversion of $\mathrm{CO}_{2}$ in an aqueous solution of $\mathrm{NaCl}$ after $1 \mathrm{~h}$ of 15 photoirradiation using $\mathrm{Ni}-\mathrm{M}^{3+}$ LDHs $\left(\mathrm{M}^{3+}=\mathrm{V}^{3+}, \mathrm{Cr}^{3+}, \mathrm{Mn}^{3+}\right.$, and $\left.\mathrm{Fe}^{3+}\right), \mathrm{Ni}-\mathrm{Al} \mathrm{LDH}$, 16 and $\mathrm{Ni}(\mathrm{OH})_{2}$. (b) Time course of the total amounts of products evolved (accumulated) 17 in the photocatalytic conversion of $\mathrm{CO}_{2}$ in an aqueous solution of $\mathrm{NaCl}$ using $\mathrm{Ni}-\mathrm{V}$ 18 LDH. Red circle: $\mathrm{CO}$, blue circle (outlined): $\mathrm{H}_{2}$.Photocatalyst weight: $500 \mathrm{mg}$, water: $191.0 \mathrm{~L}$, additive: $0.1 \mathrm{M} \mathrm{NaCl}, \mathrm{CO}_{2}$ supply: $15 \mathrm{~mL} \mathrm{~min}{ }^{-1}$, light source: $400 \mathrm{~W}$ 20 high-pressure $\mathrm{Hg}$ lamp.

21 Figure 5(a) XRD patterns of $\mathrm{Ni}-\mathrm{V}$ LDH with $\mathrm{Ni} / \mathrm{V}=$ (i) 2, (ii) 3, (iii) 4, and (iv) 5). (b)

$22 \mathrm{XRD}$ patterns of $\mathrm{Ni}_{2}-\mathrm{V}_{x}-\mathrm{Al}_{1-x}(x=$ (i) 0 , (ii) 0.1 , (iii) 0.5 , (iv) 0.7 , and (v) 1.0 , the ratio 23 of $\mathrm{Ni} /(\mathrm{V}+\mathrm{Al})$ was fixed at 2.). $x=0$ in Figure 5(b) was same as $\mathrm{Ni}-\mathrm{V}$ LDH with $\mathrm{Ni} / \mathrm{V}$ $24=2$. The characteristic peaks which are marked with black circle $(\bullet)$, white circle $(\circ)$, 
1 and triangle $(\Delta)$ are attributed to (003), (006), and (110) phase reflections of LDH

2 structure.

3 Figure 6 Formation rate of $\mathrm{CO}$ in the photocatalytic conversion of $\mathrm{CO}_{2}$ in an 4 aqueous solution of $\mathrm{NaCl}$ using $\mathrm{Ni}_{2}-\mathrm{V}_{x}-\mathrm{Al}_{1-x}(x=0,0.1,0.5,0.7$, and 1.0$)$ after $1 \mathrm{~h}$ (red 5 circle) and $5 \mathrm{~h}$ (blue circle) of photoirradiation. Photocatalyst weight: $500 \mathrm{mg}$, water:

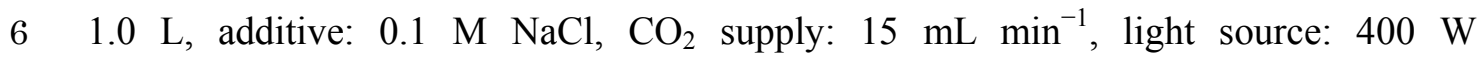
7 high-pressure Hg lamp.

8 Figure 7 Time courses of the formation rates of gas phase products (left axis) and 9 the amounts of metal ions eluted from $\mathrm{Ni}-\mathrm{V} \mathrm{LDH}$ into the reaction solution (right axis) 10 in the photocatalytic conversion of $\mathrm{CO}_{2}$ in an aqueous solution of $\mathrm{NaCl}$ for (a) $8 \mathrm{~h}$ and 11 (b) $30 \mathrm{~h}$ of photoirradiation. Red circle: $\mathrm{CO}$, blue circle: $\mathrm{H}_{2}$, green diamond: Ni ions, 12 and black diamond: V ions. Photocatalyst weight: $500 \mathrm{mg}$, water: $1.0 \mathrm{~L}$, additive: $0.1 \mathrm{M}$

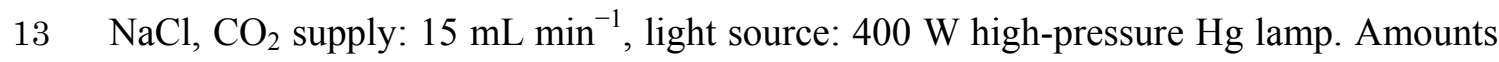
14 of metal ions eluted from $\mathrm{Ni}-\mathrm{V}$ LDH into the reaction solution were evaluated by using 15 ICP-OES at each photoirradiation time.

16 Figure 8 Time course of the total amounts of $\mathrm{CO}$ evolved (accumulated) in the 17 photocatalytic conversion of $\mathrm{CO}_{2}$ using $\mathrm{Ni}-\mathrm{V} \mathrm{LDH}$ in an aqueous solution of (a) $\mathrm{NaCl}$ $18(0.1 \mathrm{M})+\mathrm{Na}_{2} \mathrm{CO}_{3}(0.1 \mathrm{M})$ and (b) $\mathrm{NaCl}(0.1 \mathrm{M})$. Photocatalyst weight: $500 \mathrm{mg}$, water:

$191.0 \mathrm{~L}, \mathrm{CO}_{2}$ supply: $15 \mathrm{~mL} \mathrm{~min}^{-1}$, light source: $400 \mathrm{~W}$ high-pressure Hg lamp. 
Figure 1(a)

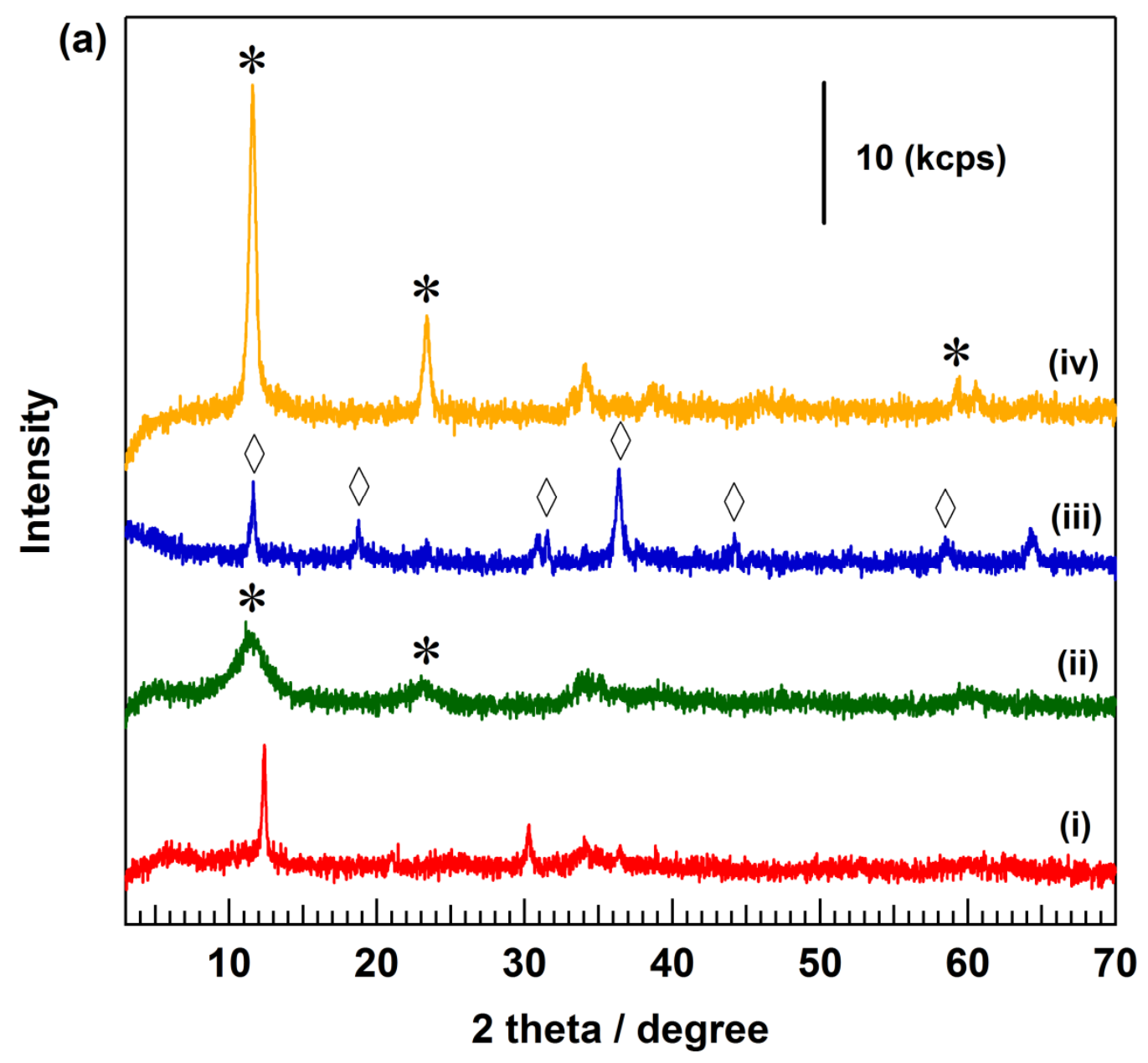


Figure 1(b)

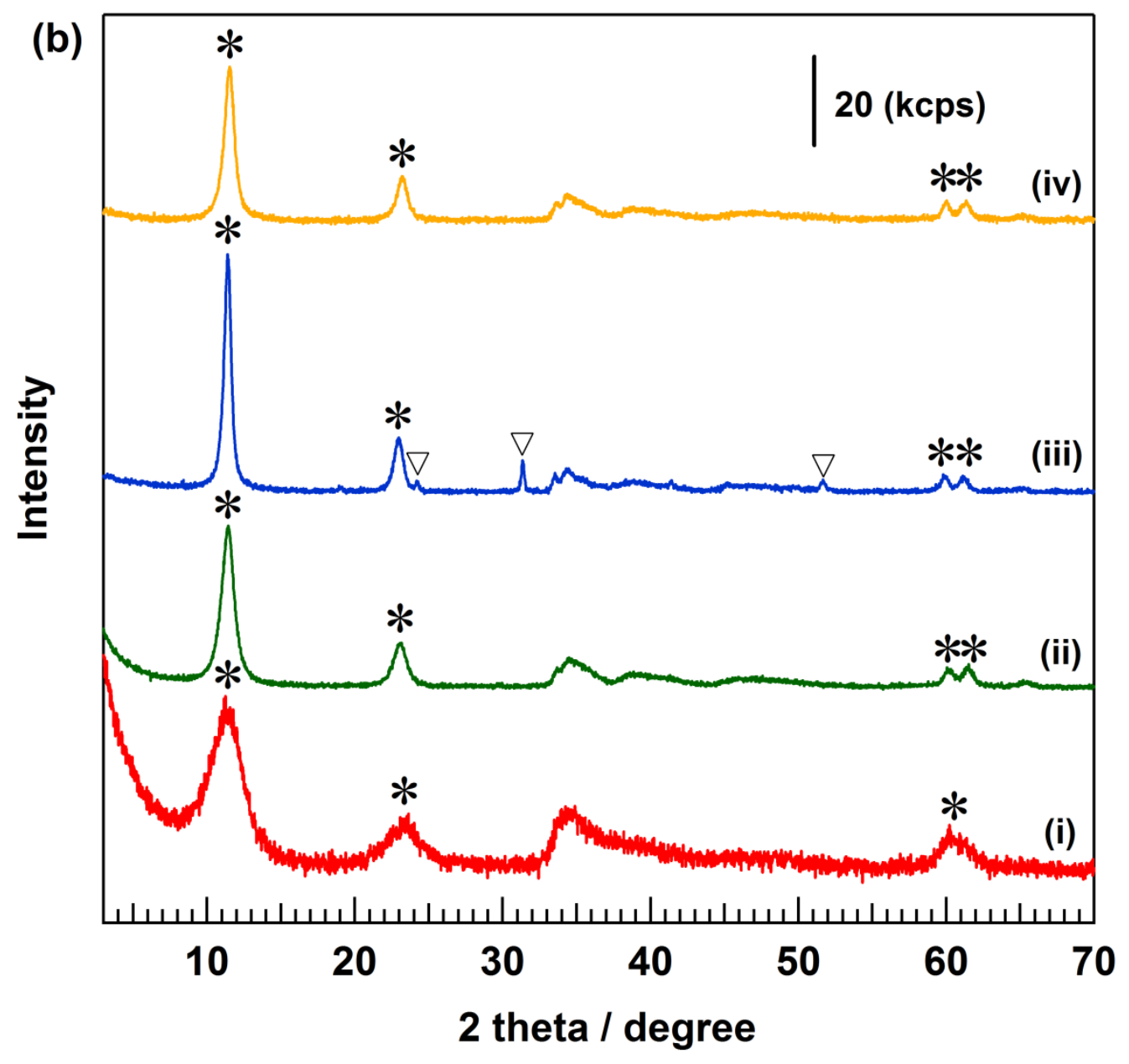


Figure 1(c)

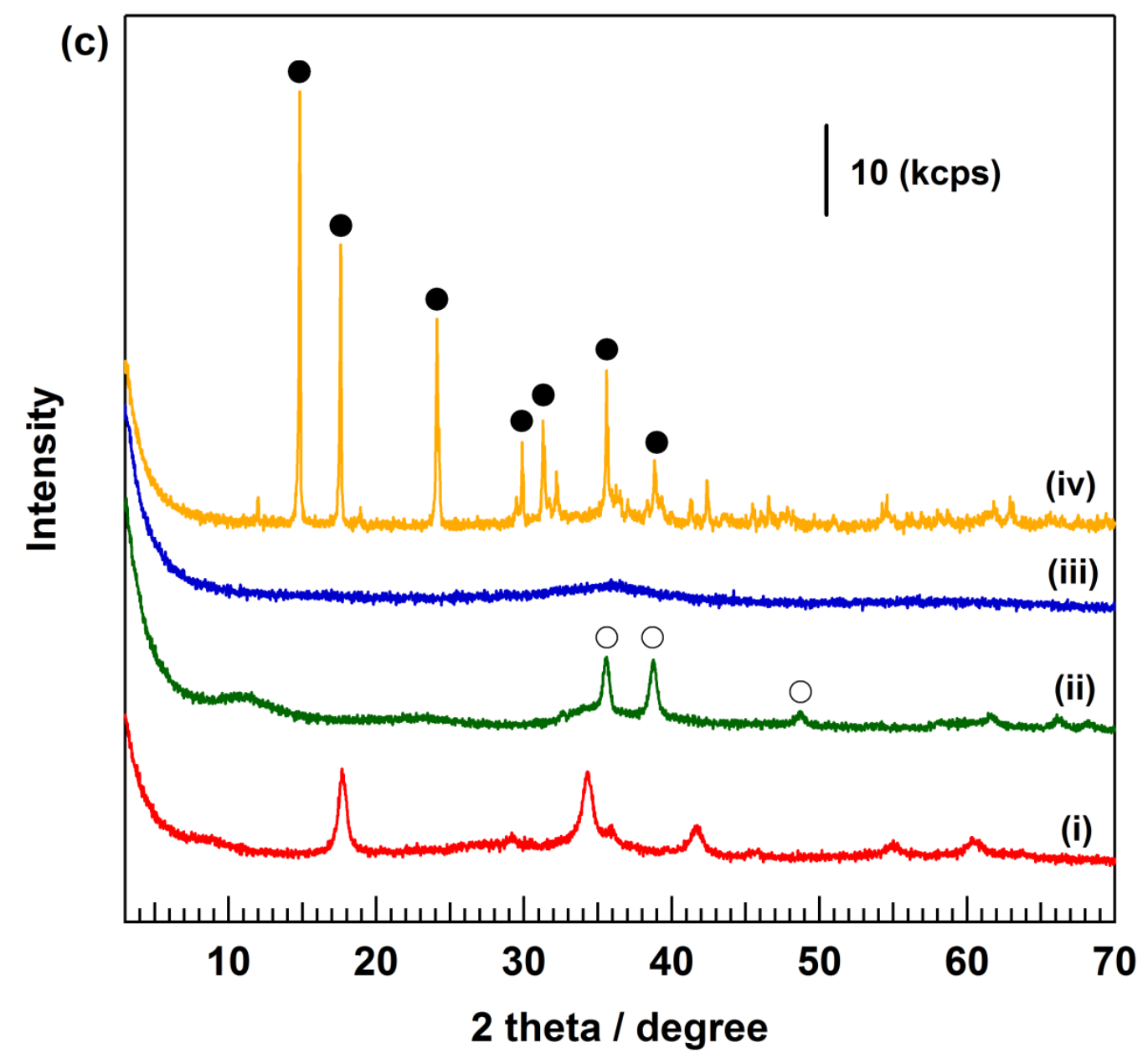


Figure 1(d)

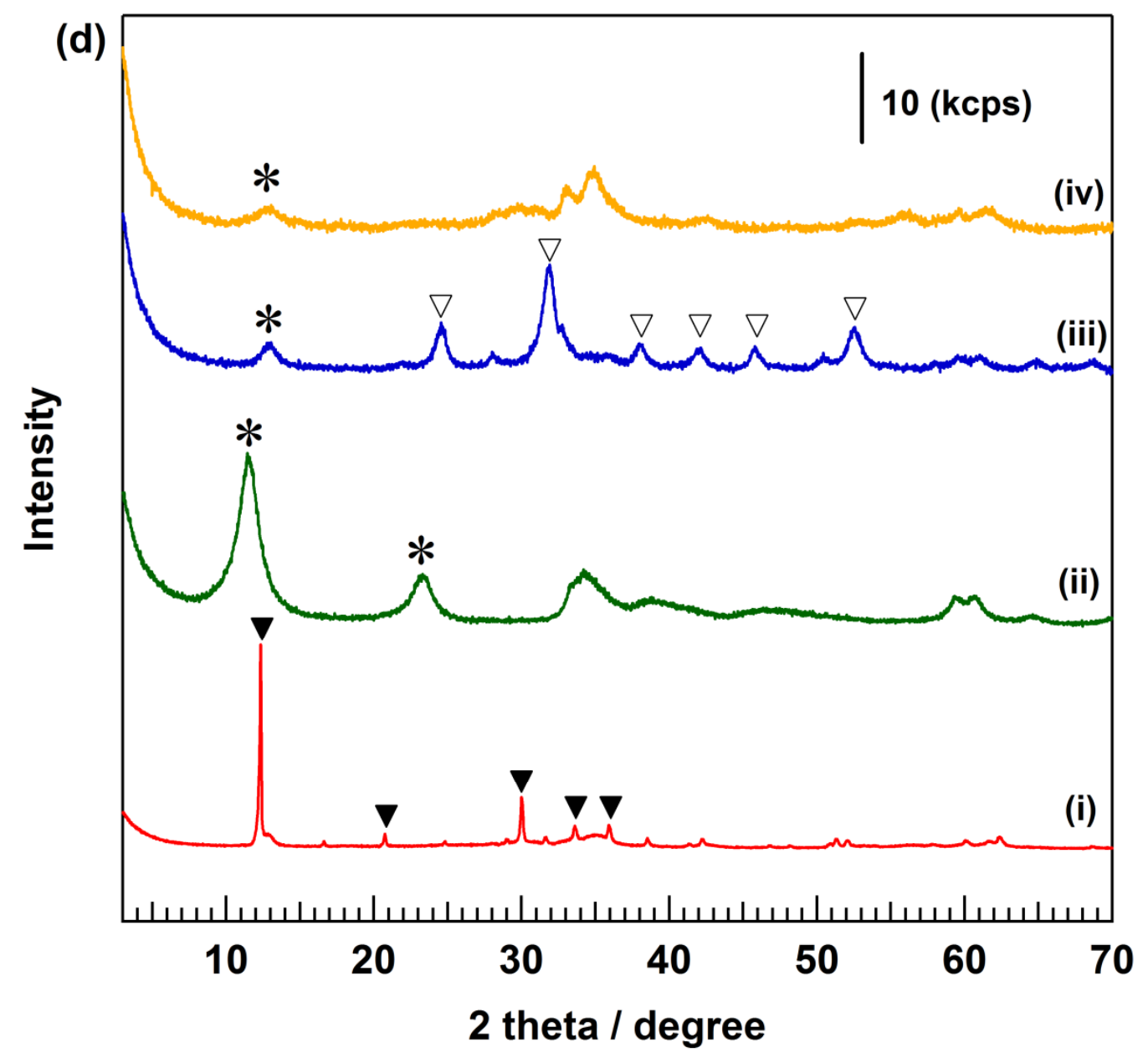


Figure 2

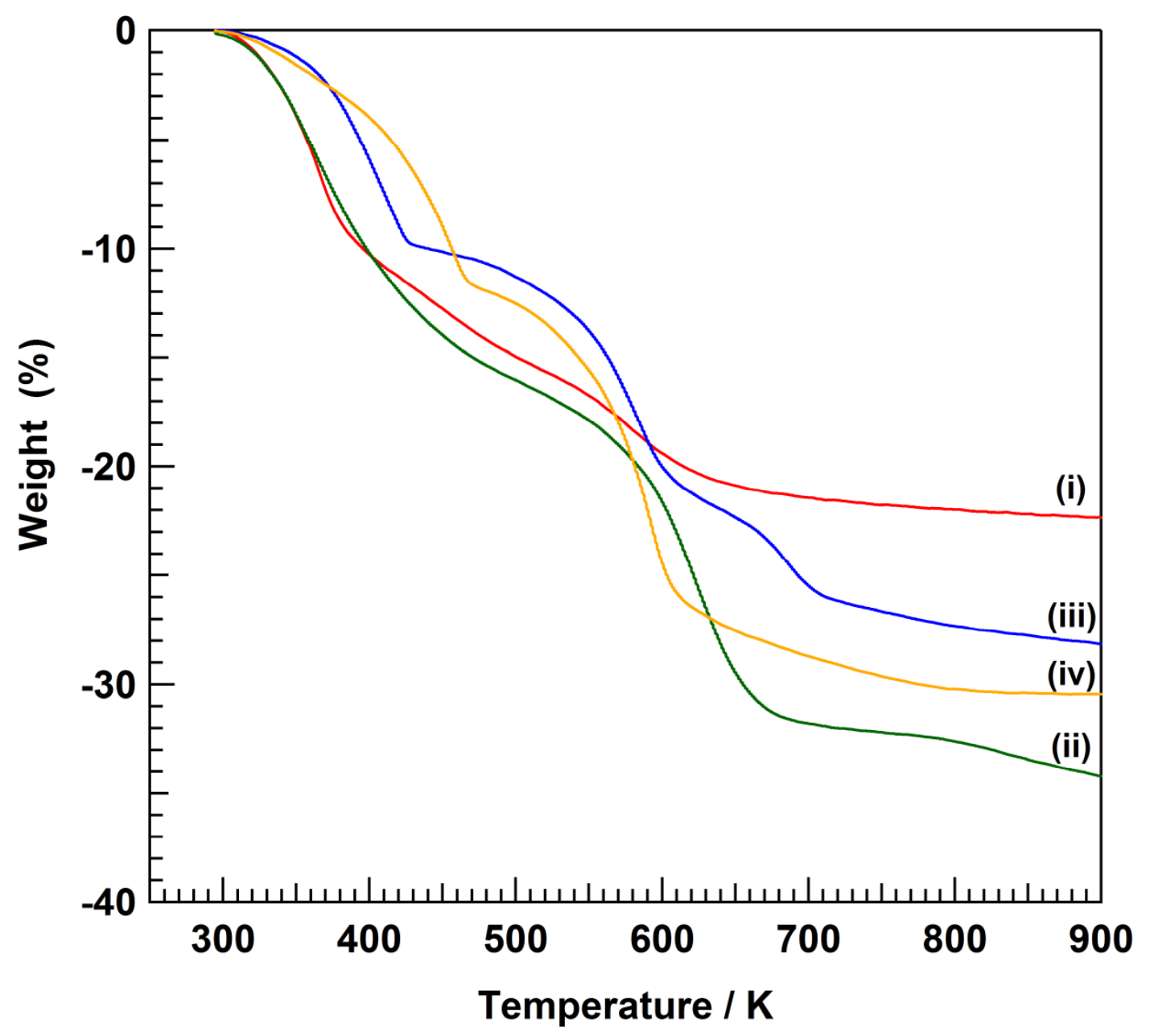


Figure 3

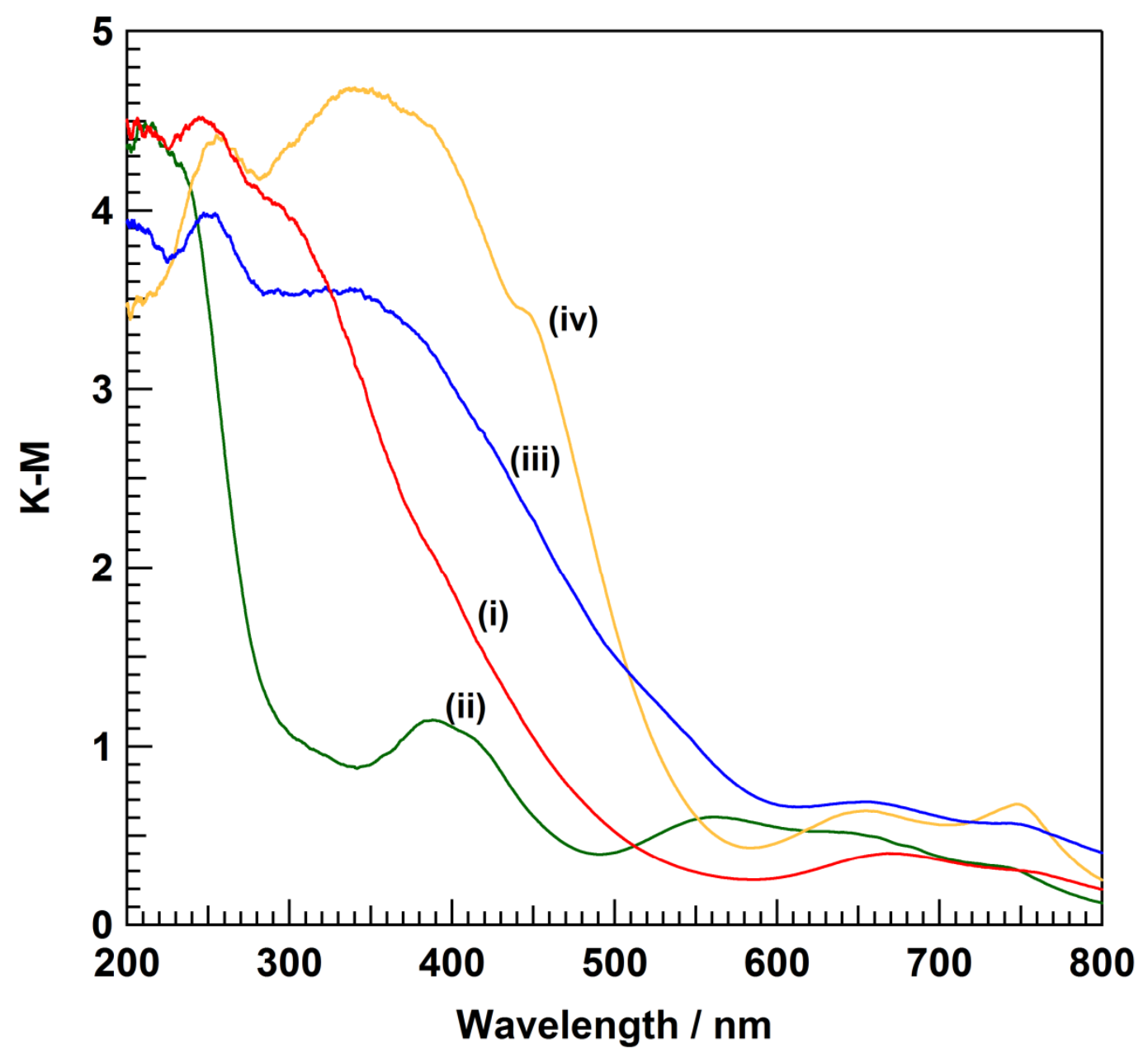


Figure 4(a)

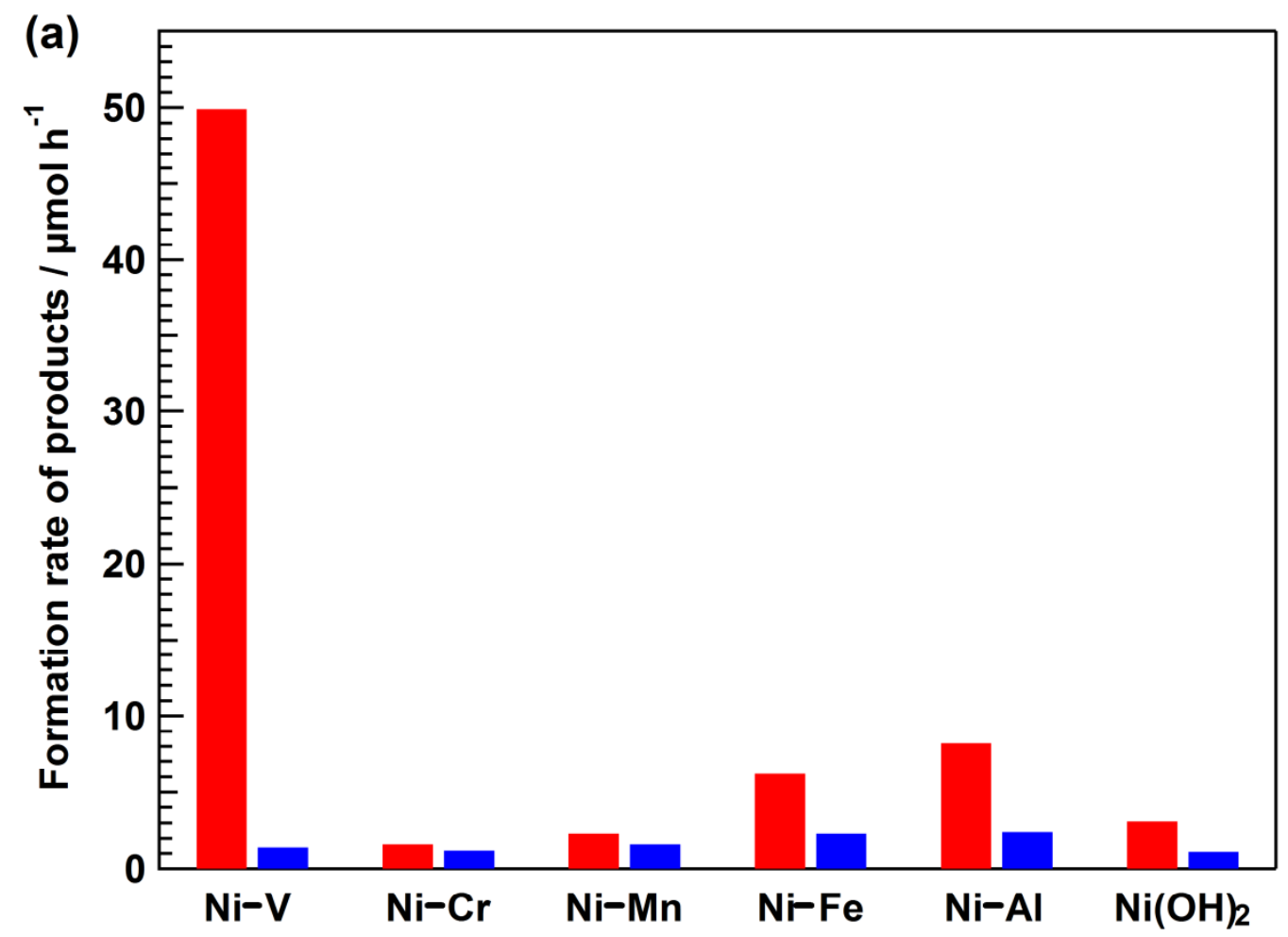


Figure 4(b)

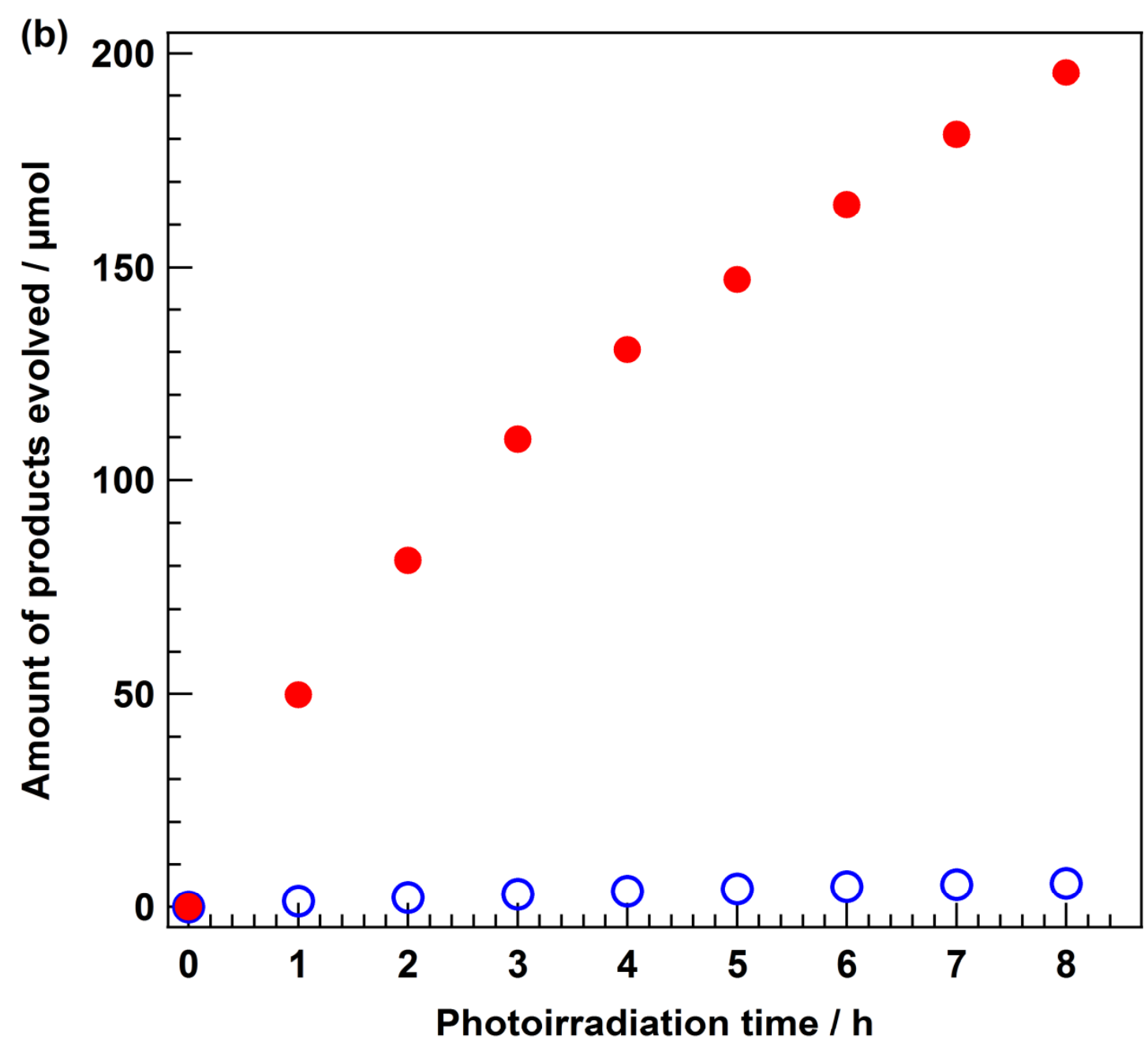


Figure 5(a)

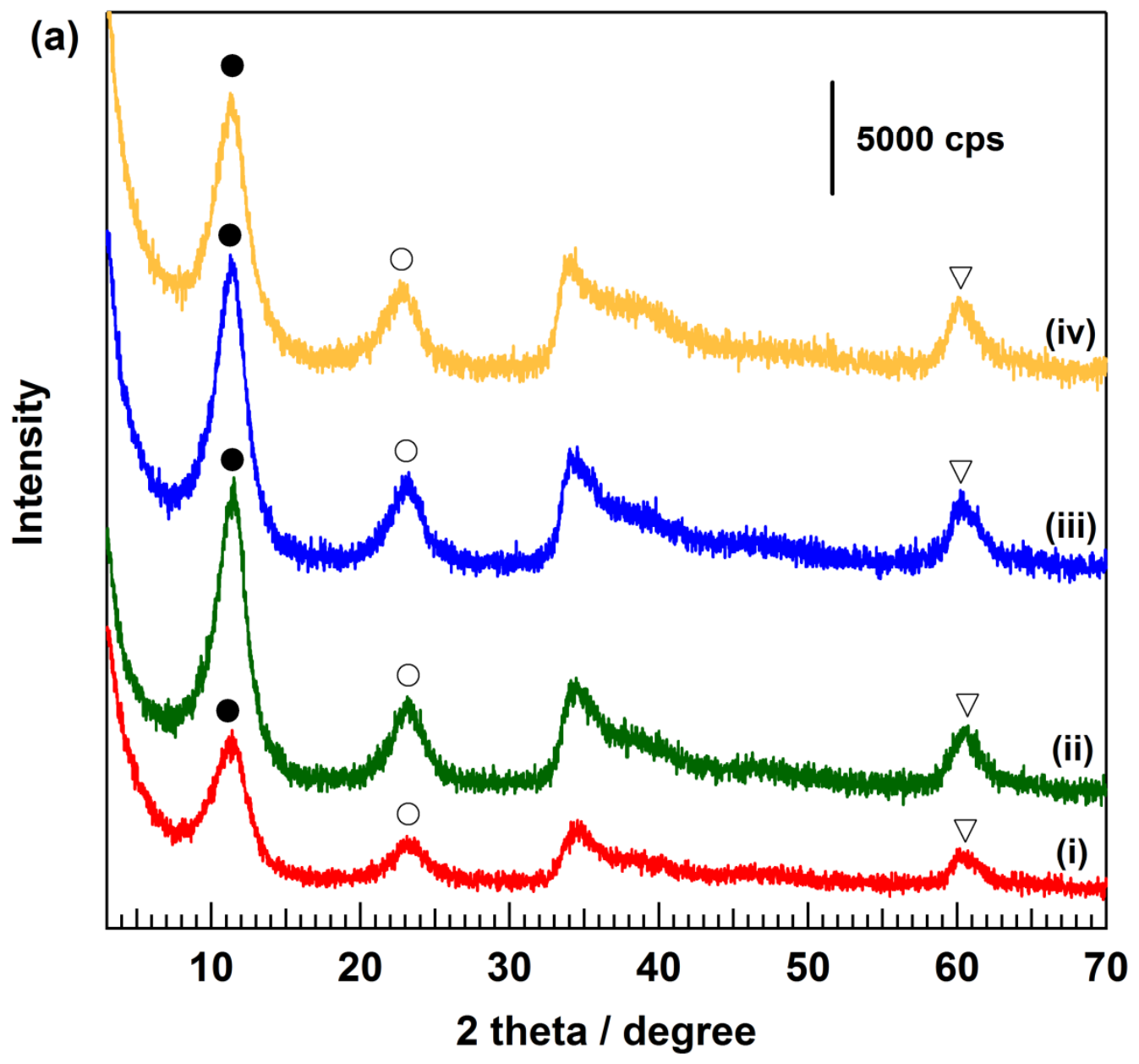


Figure 5(b)

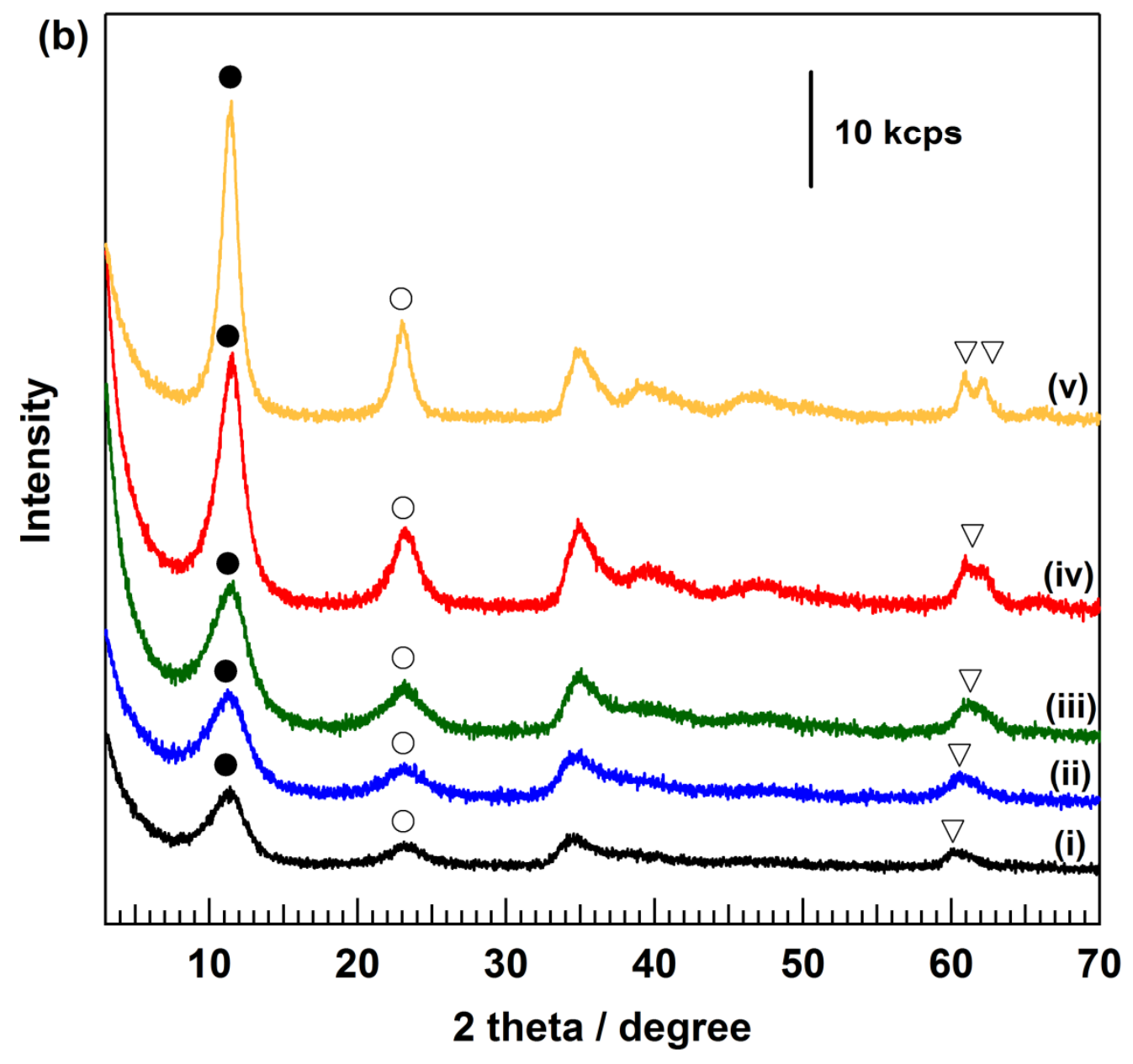


Figure 6

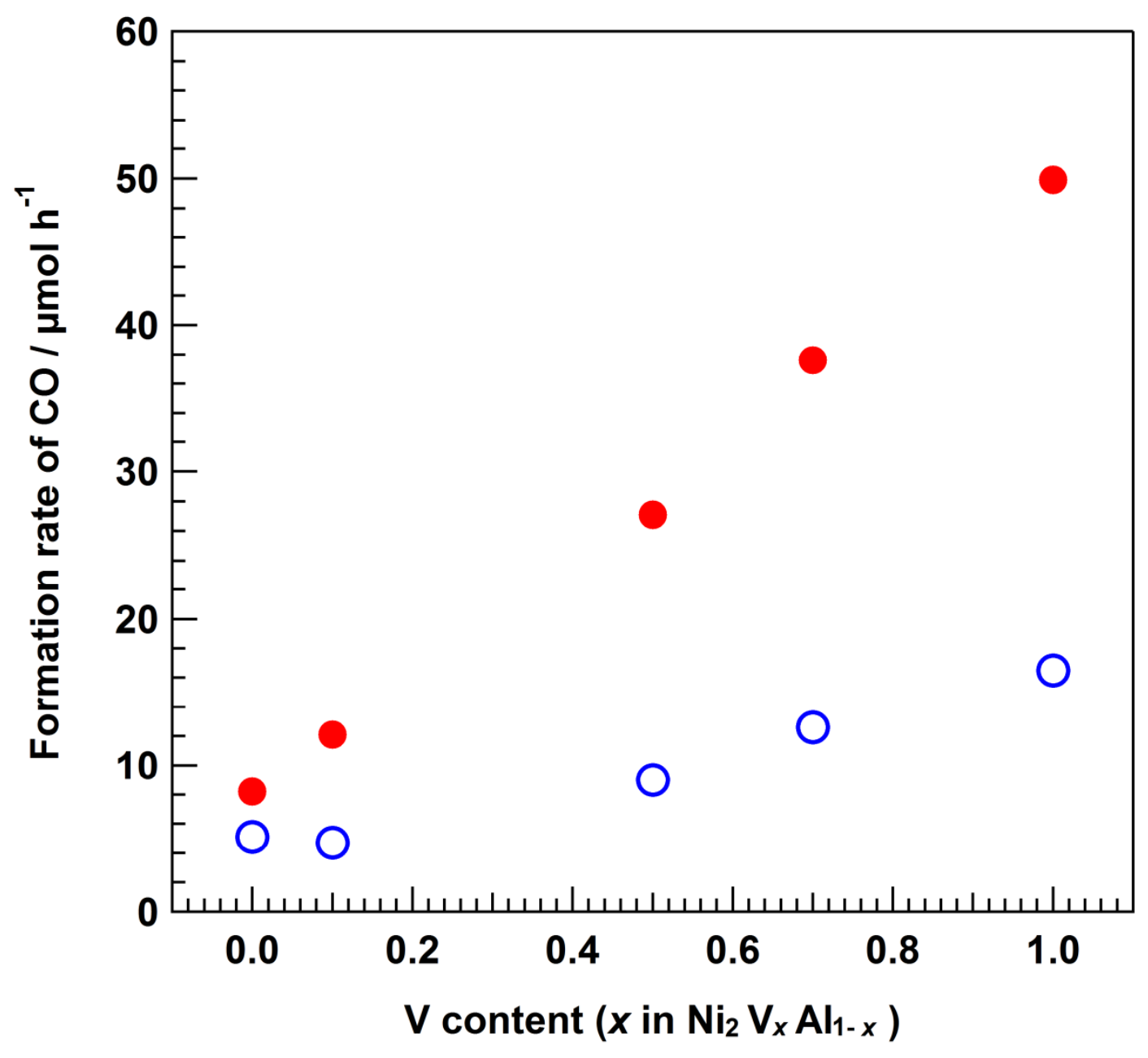


Figure 7(a)

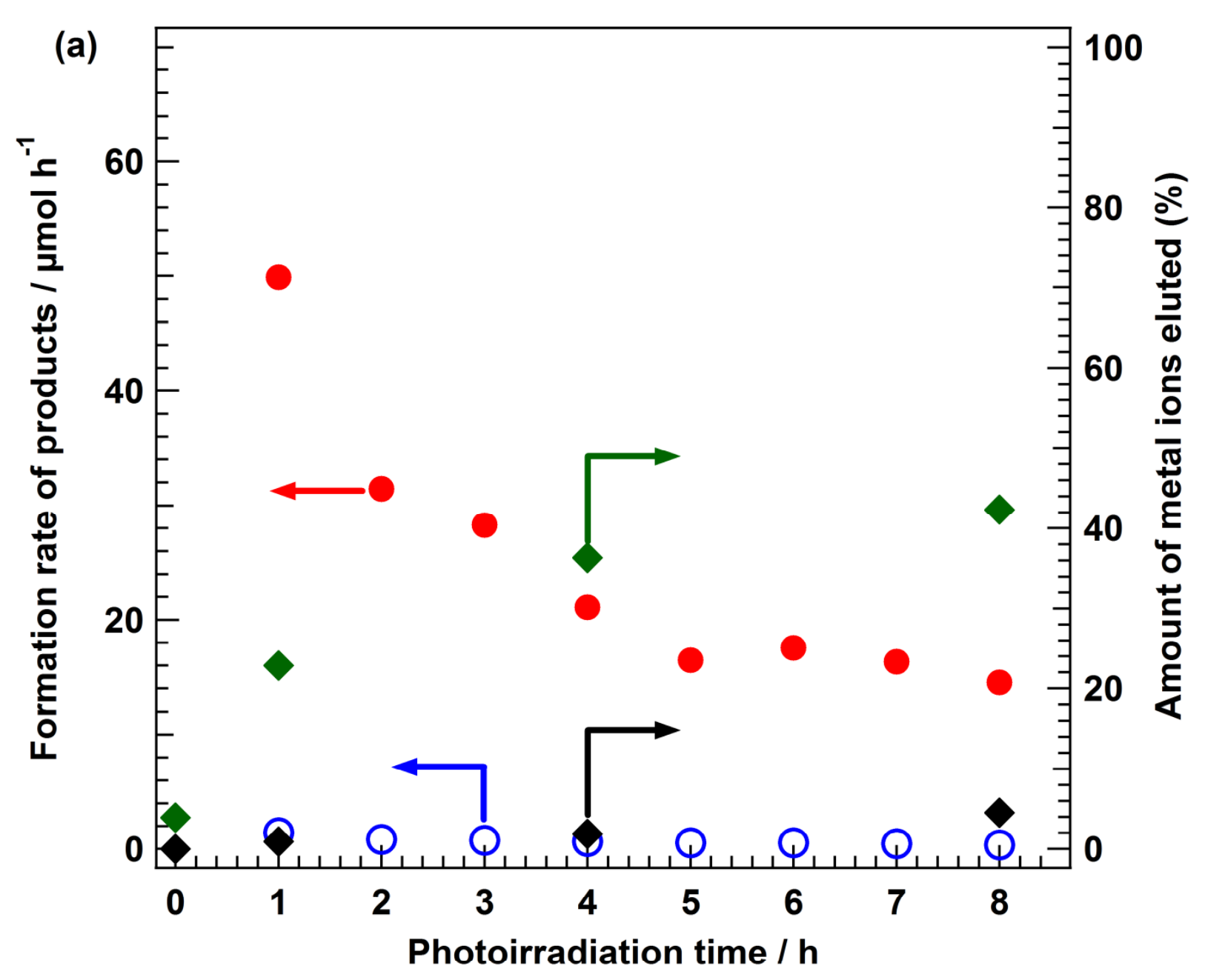


Figure 7(b)

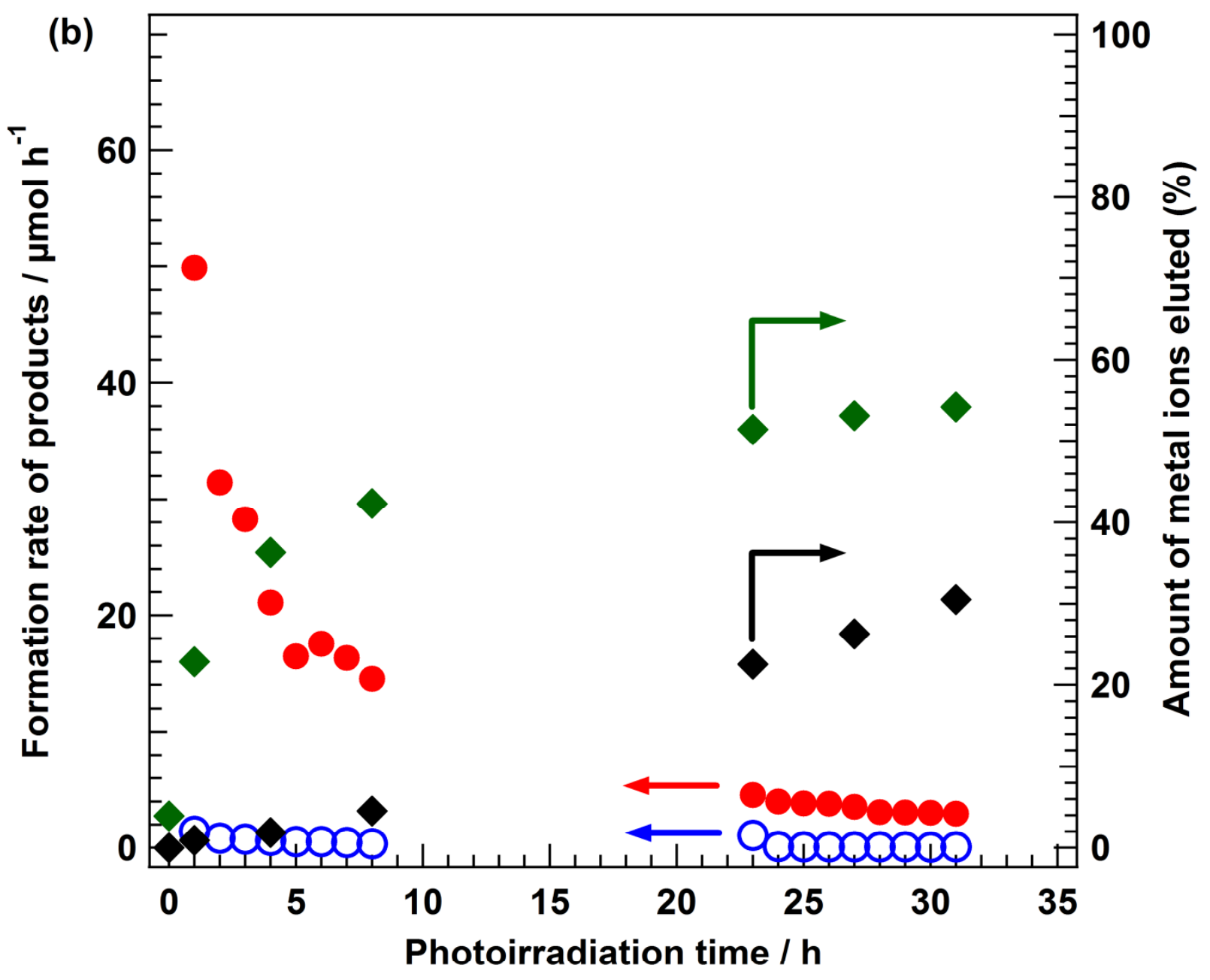


Figure 8

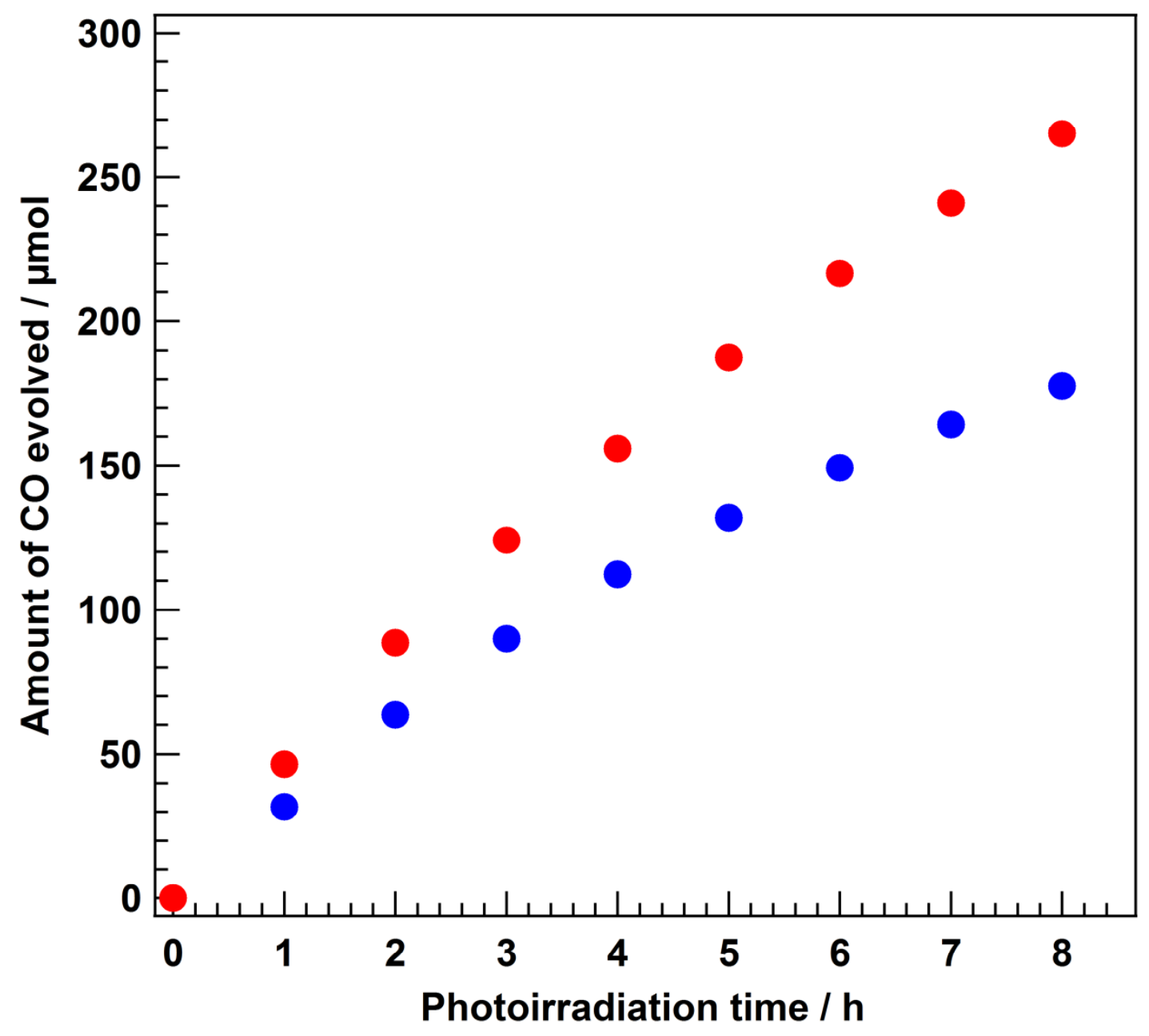




\section{$\mathrm{CO}_{2}$}

-Transition metal-coñaining Layered Double Hydroxide
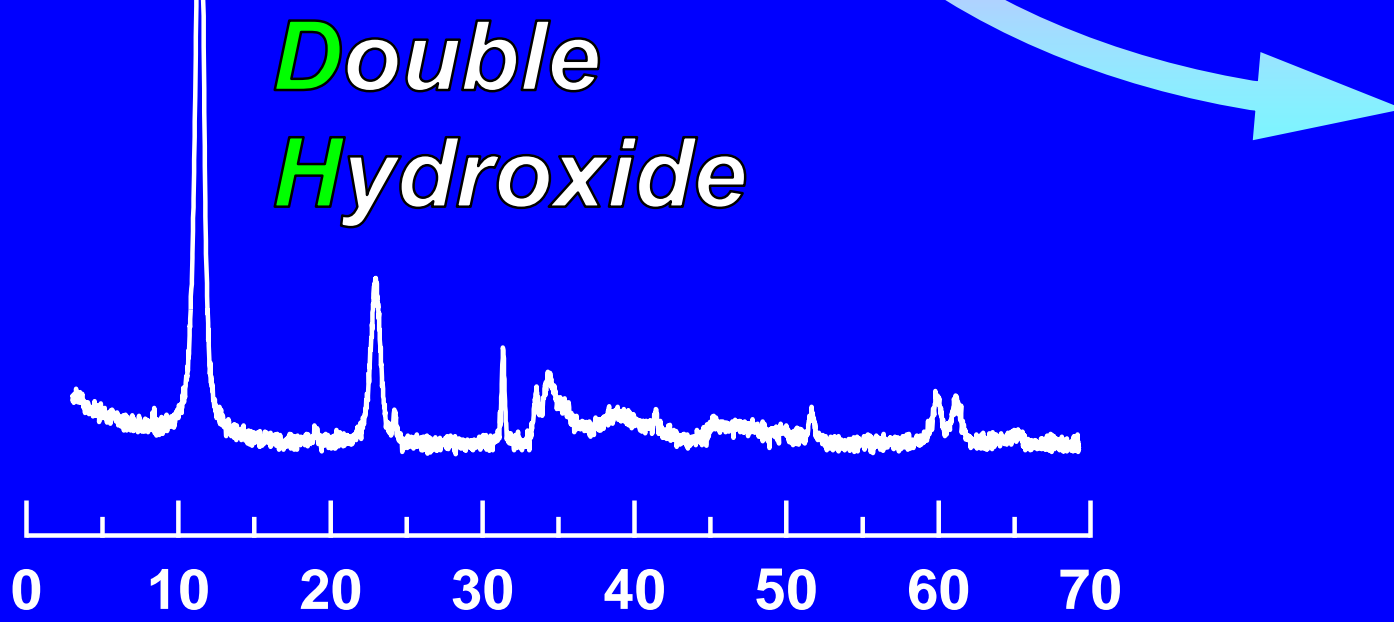

2 theta / degree 